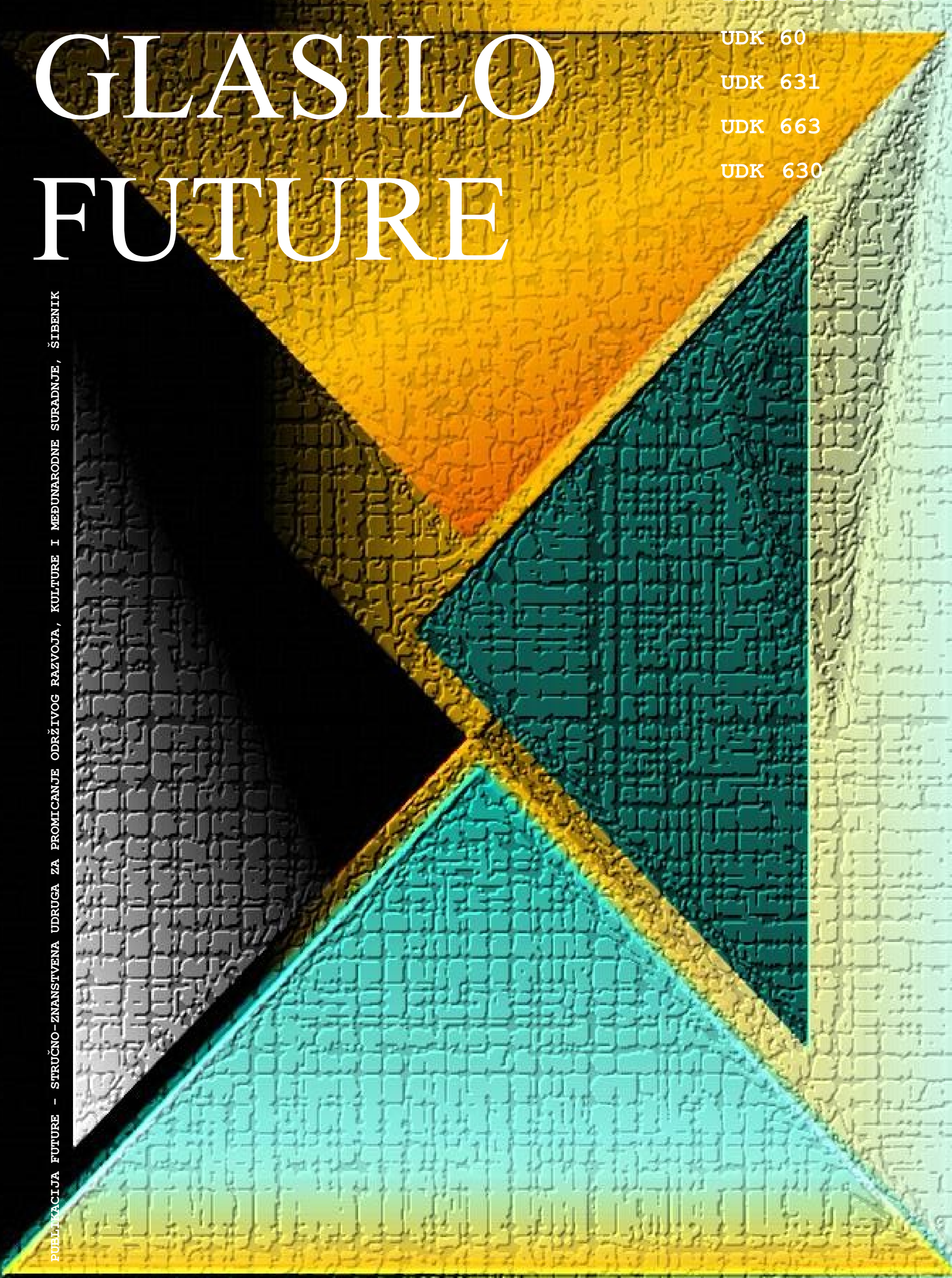

VOLUMEN 2 BROJ 5-6

PROSINAC 2019. 


\section{Glasilo Future}

\section{Stručno-znanstveni časopis}

Nakladnik:

FUTURA

\section{FuTURA}

Sjedište udruge: Šibenik

\section{Adresa uredništva:}

Bana Josipa Jelačića 13 a, 22000 Šibenik, Hrvatska / Croatia

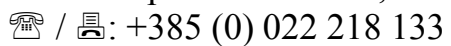

凶: urednistvo@gazette-future.eu / editors@gazette-future.eu

(3): www.gazette-future.eu

Uređivački odbor / Editorial Board:

Doc. dr. sc. Boris Dorbić, v. pred. - glavni i odgovorni urednik / Editor-in-Chief

Emilija Friganović, dipl. ing. preh. teh., v. pred. - zamjenica g. i o. urednika / Deputy Editor-in-Chief

Ančica Sečan Matijaščić, mag. act. soc. - tehnička urednica / Technical Editor

Antonia Dorbić, mag. art. - zamjenica tehničke urednice / Deputy Technical Editor

Prof. dr. sc. Željko Španjol

Mr. sc. Milivoj Blažević

Vesna Štibrić, dipl. ing. preh. teh.

Međunarodno uredništvo / International Editorial Board:

Prof. dr. sc. Kiril Bahcevandziev - Portugalska Republika (Instituto Politécnico de Coimbra)

Prof. dr. sc. Martin Bobinac - Republika Srbija (Šumarski fakultet Beograd)

Prof. dr. sc. Zvezda Bogevska - Republika Sjeverna Makedonija (Fakultet za zemjodelski nauki i hrana Skopje)

Dario Bognolo, mag. ing. - Republika Hrvatska (Veleučilište u Rijeci)

Prof. dr. sc. Agata Cieszewska - Republika Poljska (Szkoła Główna Gospodarstwa Wiejskiego w Warszawie)

Dr. sc. Bogdan Cvjetković, prof. emeritus - Republika Hrvatska (Agronomski fakultet Zagreb)

Prof. dr. sc. Duška Ćurić - Republika Hrvatska (Prehrambeno-biotehnološki fakultet Zagreb)

Prof. dr. sc. Margarita Davitkovska - Republika Sjeverna Makedonija (Fakultet za zemjodelski nauki i hrana Skopje)

Prof. dr. sc. Dubravka Dujmović Purgar - Republika Hrvatska (Agronomski fakultet Zagreb)

Prof. dr. sc. Josipa Giljanović - Republika Hrvatska (Kemijsko-tehnološki fakultet u Splitu)

Prof. dr. sc. Semina Hadžiabulić - Bosna i Hercegovina (Agromediteranski fakultet Mostar)

Prof. dr. sc. Péter Honfi - Mađarska (Faculty of Horticultural Science Budapest)

Prof. dr. sc. Valeria Ivanova - Republika Bugarska (Fakultet za lozaro - gradinarstvo Plovdiv)

Prof. dr. sc. Mladen Ivić - Bosna i Hercegovina (Univerzitet PIM)

Doc. dr. sc. Orhan Jašić - Bosna i Hercegovina (Filozofski fakultet Tuzla)

Prof. dr. sc. Tajana Krička - Republika Hrvatska (Agronomski fakultet Zagreb)

Doc. dr. sc. Dejan Kojić - Bosna i Hercegovina (Univerzitet PIM)

Slobodan Kulić, mag. iur. - Republika Srbija (Srpska ornitološka federacija i Confederation ornitologique mondiale)

Prof. dr. sc. Biljana Lazović - Crna Gora (Biotehnički fakultet Podgorica)

Prof. dr. sc. Branka Ljevnaić-Mašić - Republika Srbija (Poljoprivredni fakultet Univerziteta u Novom Sadu)

Doc. dr. sc. Zvonimir Marijanović - Republika Hrvatska (Kemijsko-tehnološki fakultet u Splitu)

Doc. dr. sc. Ana Matin - Republika Hrvatska (Agronomski fakultet Zagreb)

Prof. dr. sc. Bosiljka Mustać - Republika Hrvatska (Sveučilište u Zadru)

Hrv. akademik prof. dr. sc. Stanislav Nakić - Bosna i Hercegovina (Sveučilište Hercegovina Mostar)

Sandra Popović, mag. ing. - Republika Srbija (Poljoprivredni fakultet Beograd)

Doc. dr. sc. Bojan Simovski - Republika Sjeverna Makedonija (Fakultet za šumarski nauki, pejzažna arhitektura i

ekoinženering "Hans Em" Skopje)

Prof. dr. sc. Davor Skejić - Republika Hrvatska (Građevinski fakultet Zagreb)

Doc. dr. sc. Milan Stanković - Republika Srbija (Univerzitet u Kragujevcu)

Akademik prof. dr. sc. Refik Šećibović - Bosna i Hercegovina (Visoka škola za turizam i menadžment Konjic)

Prof. dr. sc. Andrej Šušek - Republika Slovenija (Fakulteta za kmetijstvo in biosistemske vede Maribor)

Prof. dr. sc. Elma Temim - Bosna i Hercegovina (Agromediteranski fakultet Mostar)

Mr. sc. Merima Toromanović - Bosna i Hercegovina (Biotehnički fakultet Univerziteta u Bihaću)

Doc. dr. sc. Ivana Vitasović Kosić - Republika Hrvatska (Agronomski fakultet Zagreb)

Doc. dr. sc. Ana Vujošević - Republika Srbija (Poljoprivredni fakultet Beograd)

Prof. dr. sc. Vesna Židovec - Republika Hrvatska (Agronomski fakultet Zagreb)

Lektura i grafička priprema: Ančica Sečan Matijaščić, mag. act. soc.

Objavljeno: 31. prosinca 2019. godine.

Časopis izlazi u elektroničkom izdanju dva puta godišnje, krajem lipnja i prosinca, a predviđena su i dva interdisciplinarna specijalna izdanja

tijekom godine iz STEM i ostalih znanstvenih/umjetničkih područja.

C̆asopis je besplatan. Rukopisi i recenzije se ne vraćaju i ne honoriraju.

Umnožavanje (reproduciranje), stavljanje u promet (distribuiranje), priopćavanje javnosti, stavljanje na raspolaganje javnosti odnosno prerada u bilo kojem obliku nije dopuštena bez pismenog dopuštenja Nakladnika.

Sadržaj objavljen u Glasilu Future može se slobodno koristiti u osobne i obrazovne svrhe uz obvezno navođenje izvora. 


\section{Glasilo Future}

\section{Stručno-znanstveni časopis}

FUTURA - stručno-znanstvena udruga za promicanje održivog razvoja, kulture i međunarodne suradnje, Bana Josipa Jelačića 13 a, 22000 Šibenik, Hrvatska

(2019) $2(5-6)$ 01-72

\section{SADRŽAJ:}

Izvorni znanstveni rad (original scientific paper)

Str.

Ivana Gašparović, Ž. Španjol, B. Dorbić, I. Tolić, Irena Milčić

Perivoj dvorca Kulmer-Bračak (Republika Hrvatska) - biološko i prostorno vrednovanje The public garden of the Kulmer-Bračak Castle (The Republic of Croatia) - biological and spatial evaluation

Emilija Friganović, Nikolina Tokmakčija, Ančica Sečan Matijaščić, M. Kelava, Mladenka Šarolić, B. Dorbić

Salmonella spp. in RASFF notifications involving Croatia in the period from 01/01/2014 to $31 / 12 / 2018$

T. Svalina, Sara Nasić, M. Šuste, Žana Delić, Emilija Friganović, Mladenka Šarolić, B.

Dorbić

Aromatski profil kupinovih vina

Aromatic profile of blackberry wines

Mladenka Šarolić, Nikolina Bosnić, Emilija Friganović, Žana Delić, M. Šuste, T. Svalina, B.

Dorbić, Z. Marijanović

Kemijska analiza hlapljivih spojeva tradicionalne rakije Anižete s otoka Korčule - Republika Hrvatska

Chemical analysis of volatile compounds of traditional brandy Anižeta from the island of Korčula - Republic of Croatia

\section{Stručni rad (professional paper)}

Doroteja Benko, Ivana Vitasović-Kosić

Primjena utilitarnog i ukrasnog bilja u razdoblju baroka na primjeru dvoraca Hrvatskog zagorja

Use of utilitarian and ornamental plants in the Baroque period on the example of castles in Hrvatsko zagorje 


\section{Riječ glavnog urednika}

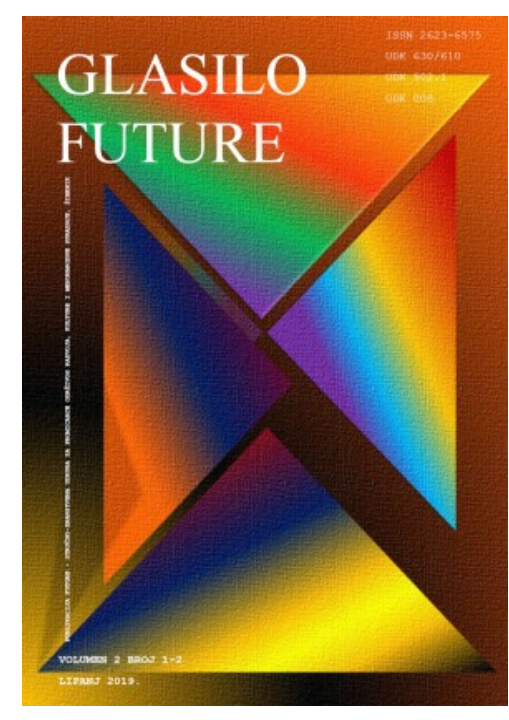

U "Glasilu Future" ove godine objavljeno je šest brojeva, dva specijalna (interdisciplinarna izdanja) i dva redovita broja (biotehničko područje). Ukupno je objavljeno 19 kategoriziranih članaka (16 znanstvenih i 3 stručna). Toplo zahvaljujem svim autorima na člancima koje su pripremili za Glasilo. Naši recenzenti uglavnom su domaći i inozemni sveučilišni i veleučilišni nastavnici te im ovim putem zahvaljujem na trudu oko recenzije radova za naš časopis. Uredništvo je i ove godine uložilo napor da uvrsti ili pokrene postupak uvrštavanja časopisa $u$ različite međunarodne znanstvene baze. Također zahvaljujem na radu i našem međunarodnom uredništvu kojeg čini 35 uglednih znanstvenika i stručnjaka iz 25 različitih institucija i 11 zemalja. Od ove godine imamo ostvarenu suradnju i s nekoliko znanstvenih i znanstveno-popularnih časopisa iz Hrvatske i inozemstva. Pozivamo Vas da i dalje objavljujete vaše radove u našem časopisu.

Srdačno vaš,

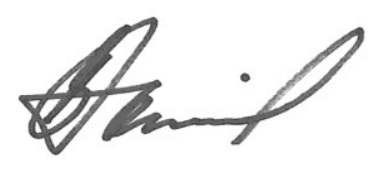

Doc. dr. sc. Boris Dorbić, viši predavač 
Ivana Gašparović, Ž. Španjol, B. Dorbić, I. Tolić, Irena Milčić / Perivoj dvorca Kulmer-Bračak (Republika Hrvatska) - biološko i prostorno vrednovanje / Glasilo Future (2019) 2 (5-6) 01-23

\title{
Perivoj dvorca Kulmer-Bračak (Republika Hrvatska) - biološko i prostorno vrednovanje
}

\section{The public garden of the Kulmer-Bračak Castle (The Republic of Croatia) - biological and spatial evaluation}

\author{
Ivana Gašparović ${ }^{1}, \check{Z ̌ e l j k o ~ S ̌ p a n j o l ~}^{2 *}$, Boris Dorbić ${ }^{3}$, Ivan Tolić ${ }^{4}$, Irena Milčić ${ }^{5}$ \\ izvorni znanstveni rad (original scientific paper) \\ doi: 10.32779/gf.2.5-6.1
}

\section{Sažetak}

Dvorac Kulmer s posjedom Bračak smješten je kao samostalna građevina na zaravni brežuljka koji se uzdiže sjeverno od ceste koju prate željeznička pruga i rijeka Krapina. Okružen je perivojem koji prekriva cijelu južnu padinu do same ceste. Nova namjena ove građevine određena je da bude javna i to $\mathrm{u}$ funkciji edukacijsko-prezentacijskog centra $\mathrm{s}$ uredskim i ugostiteljskim prostorima.Kulmer, Bračak spada u kategoriju preventivno zaštićenih kulturnih dobara u kategoriji Perivoji i parkovi, predložen je za upis u registar nepokretnih kulturnih dobara Republike Hrvatske. Gubitak izvornog identiteta perivoja događa se tijekom minulog stoljeća uslijed širenja bolničkog kompleksa i uslijed neadekvatnog održavanja, što uvjetuje njegovu degradaciju i gubitak kompozicijske osnove. Prilikom izrade ovog rada korištene su metode analize, sinteze i komparativne metode. Cilj rada je bila biološko-ekološka i krajobrazna valorizacija i ukazati na smjernice uređenja perivoja Kulmer-Bračak. Istraživanja su obavljena 2011., 2015. i 2016. godine. U radu se ujedno kao cilj provela revitalizacija prostora perivoja kao metodu vraćanja života u zapuštene perivoje u cilju vraćanja prvobitne ili pridavanjem neke druge primjerene funkcije. Kako su u vrijeme obavljanja naših istraživanja započeti radovi na obnovi dvorca i znala se njegova buduća funkcija kao sjedišta Regionalnog energetskog centra predložene smjernice uređenja i vrednovanja perivoja vođene su tom činjenicom. Kod odabira vrsta za sadnju predviđene su autohtone vrste i vrste koje su kroz povijest evidentirane u perivojima na području Hrvatskog zagorja. U smislu revitalizacije pojedinih funkcionalnih sadržaja i njihovo lociranje je predviđeno u odnosu na postojeći dvorac, povijesnu matricu perivoja te spomenutu buduću namjenu dvorca, a time i korištenje perivoja. Regionalni energetski centar u dvorcu Kulmer-Bračak otvoren je u ožujku 2017. godine dok radovi na potpunom funkcionalnom uređenju perivoja nisu urađeni.

\footnotetext{
${ }^{1}$ Vile Velebita 30, 10000 Zagreb, Republika Hrvatska.

2 Šumarski fakultet Sveučilišta u Zagrebu, Svetošimunska cesta 25, 10000 Zagreb, Republika Hrvatska.

*E-mail: zspanjol@sumfak.hr.

${ }^{3}$ Veleučilište "Marko Marulić" u Kninu, Petra Krešimira IV 30, 22300 Knin, Republika Hrvatska.

${ }^{4}$ Zagreb, Republika Hrvatska.

${ }^{5}$ Zagreb, Republika Hrvatska.
} 
Ivana Gašparović, Ž. Španjol, B. Dorbić, I. Tolić, Irena Milčić / Perivoj dvorca Kulmer-Bračak (Republika Hrvatska) - biološko i prostorno vrednovanje / Glasilo Future (2019) 2 (5-6) 01-23

Ključne riječi: Kulmer-Bračak, perivoj, dendroflora, vrednovanje, krajobrazno uređenje.

\begin{abstract}
The Kulmer-Bračak Castle is located as an independent structure on the plateau of the hill that rises to the North of the road that is accompanied by the railway and the Krapina River. It is surrounded by the public garden that covers the entire southern slope to the road itself. The new purpose of this structure is to be open to the public, intended as an educational and presentational centre with office and catering facilities.
\end{abstract}

The Kulmer-Bračak Castle is classified in the category of preventively protected cultural heritage, more specifically in the category of public gardens and parks and a proposal has been put forward for its entry in the Immovable Cultural Heritage Registry of the Republic of Croatia. A loss of the original identity of the public garden occurred in the past century amidst the expansion of the hospital complex and inadequate maintenance, which caused its degradation and a loss of its compositional basis. Methods of analysis, synthesis and comparative methods were resorted to upon the preparation of this paper. The specific objective of the paper was biological-ecological and landscape valorisation, as well as to point out the guidelines used in terms of landscaping of the Kulmer-Bračak Public Garden. The research was conducted in 2011, 2015 and in 2016. Moreover, another objective of the paper was the revitalisation of the area covered by the public garden, as a method for reviving the neglected public gardens in order to restore their original function or allocate them another adequate function. Since castle restoration work started during the period in which our research was conducted and its subsequent function as the headquarters of the Regional Energy Centre was already known, the proposed guidelines in terms of landscaping and evaluation of the public garden were based on that fact. Autochthonous species and species recorded throughout history in the Croatian region of Zagorje were planned upon the selection of the species for planting. Concerning revitalisation of individual functional content, its location is also envisaged in relation to the existing castle, the historical matrix of the public garden and the previously mentioned future purpose of the castle and hence also the use of the public garden. Regional Energy Centre in the Kulmer-Bračak Castle was opened in March 2017, while the work on full functional landscaping of the public garden has not been performed.

Key words: Kulmer-Bračak, public gardens, dendroflora, valorisation, landscaping.

\title{
Uvod
}

Posjed Bračak nalazi se nedaleko grada Zaboka u naselju Bračak uz cestu Zabok - Bedekovčina u krugu Opće bolnice Zabok. Dvorac Kulmer smješten je kao samostojeća građevina na zaravni brežuljka koji se uzdiže sjeverno od ceste koju prate željeznička pruga i rijeka Krapina. Dvorac je okružen perivojem koji prekriva cijelu južnu padinu do same ceste. Pristup dvorcu moguć je iz dva smjera, asfaltiranom cestom iz smjera jugozapada i smjera jugoistoka. Predmetne ceste ujedno određuju prostornu cjelinu perivoja. 
Ivana Gašparović, Ž. Španjol, B. Dorbić, I. Tolić, Irena Milčić / Perivoj dvorca Kulmer-Bračak (Republika Hrvatska) - biološko i prostorno vrednovanje / Glasilo Future (2019) 2 (5-6) 01-23

Prostor dvorca Kulmer, koji sada obuhvaća predmetnu k. č. br. 219, dan je u koncesiju Regionalnoj energetskoj agenciji Sjeverozapadne Hrvatske (REGEA). Nova namjena građevine određena je kao javna u funkciji edukacijsko-prezentacijskog centra s uredskim i ugostiteljskim prostorima te je ista u fazi uređenja.

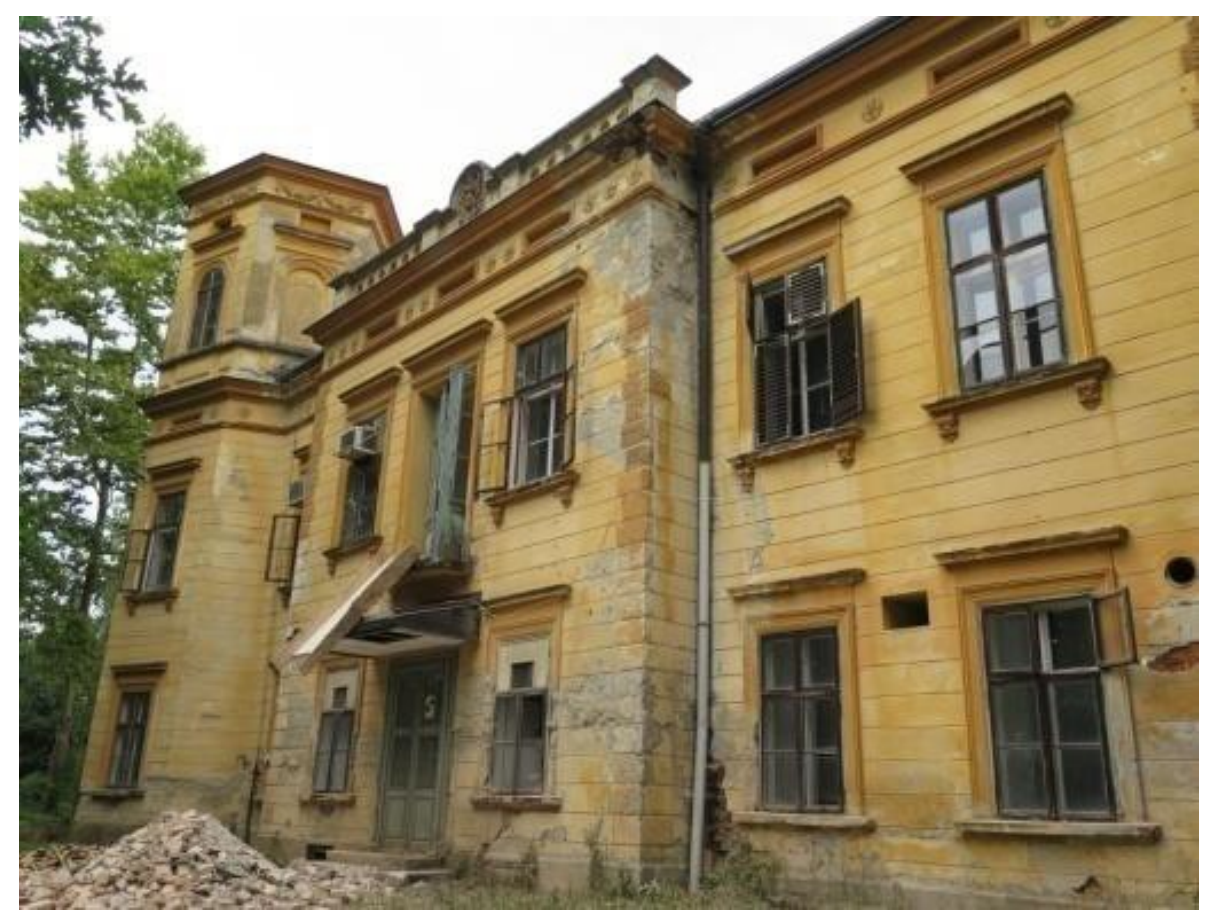

Slika 1. Prikaz dvorca koji je danas u fazi obnove i prenamjene u energetski centar (Foto: I. Gašparović).

Figure 1. View of the castle which is today in currently undergoing renovation and conversion into an energy center (Photo: I. Gašparović).

Sukladno Zakonu o zaštiti i očuvanju kulturnih dobara (NN br. 69/99, 151/03 i 157/03) i Pravilniku o Registru kulturnih dobara Republike Hrvatske (NN br. 37/01 i 04/08) Ministarstvo kulture 2009. godine donosi Rješenje o zaštiti dvorca Kulmer u Bračku kao kulturnog dobra u kategoriji nepokretno kulturno dobro - pojedinačno klasificirano kao profana graditeljska baština, zavedeno pod oznakom Z-4109. Prema Prostornom planu uređenja Grada Zaboka (2009.), I. Izmjene i dopune PPUGZ (2011.), II. Izmjene i dopune PPUGZ (2013.) i III. Izmjene i dopune PPUGZ (2015.) perivoj dvorca Kulmer, Bračak spada u kategoriju preventivno zaštićenih kulturnih dobara u kategoriji Perivoji $i$ parkovi predloženih za upis u registar nepokretnih kulturnih dobara. Od vremena nastanka do danas prostor perivoja doživljava niz promjena uvjetovanih različitim društveno-ekonomskim okolnostima koje su se događale kroz povijest, a koje se događaju i danas. Gubitak izvornog identiteta perivoja događa se dugi niz godina uslijed širenja bolničkog kompleksa te kao posljedica nedostatka neophodnih mjera održavanja, što uvjetuje njegovu degradaciju i gubitak kompozicijske osnove.

U radu se ujedno kao cilj htjelo stvoriti povoljne uvjete za opstanak prostora perivoja kao kulturnog dobra koji zajedno s dvorcem treba sagledavati kao nedjeljivu cjelinu te istovremeno uspostaviti uvjete da perivoj svojom namjenom bude u skladu s budućom namjenom prostora dvorca i time zadovoljava 
Ivana Gašparović, Ž. Španjol, B. Dorbić, I. Tolić, Irena Milčić / Perivoj dvorca Kulmer-Bračak (Republika Hrvatska) - biološko i prostorno vrednovanje / Glasilo Future (2019) 2 (5-6) 01-23

potrebe pojedinca kao i opće interese, a da se pri tome ne promijeni ili ugrozi njegova izvornost i vrijednost. Time se prvenstveno misli na revitalizaciju prostora perivoja kao metodu vraćanja života u zapuštene perivoje vraćanjem prvobitne ili pridavanjem neke druge primjerene funkcije, a da time ne ugrozimo osnovni karakter prostora.

\section{Materijali i metode}

U radu su korištene metode analize, sinteze i komparativne metode. Time je obuhvaćeno prikupljanje postojeće arhivske građe, kartografskih prikaza i katastarskih podloga vezanih za perivoj kao i terensko istraživanje koje obuhvaća inventarizaciju i analizu postojećeg stanja perivoja. Na temelju prikupljenog materijala i izvedenih inventarizacija i analiza proizlaze podaci o temeljnim obilježjima prostora perivoja, biološkim vrijednostima flore i staništa te krajobrazne, oblikovne, stilske i kulturno povijesne vrijednosti. Na temelju takvih analiza proizaći će vrednovanje perivoja i mogućnosti njegove obnove i uređenja. Analiza povijesnih karata je provedena prikupljanjem i sistematizacijom arhivske građe te njegovom interpretacijom. Istraživanja su obavljena 2011. i 2015. godine.

\section{Geneza perivoja dvorca Kulmer}

Posjed Bračak, nekad zvan i Obračak i Prilesje, pripadao je plemićkim obiteljima Kanotay, zatim Čegel da bi 1887. godine postao vlasništvo grofa Milana Kulmera. Na mjestu današnjeg dvorca postojala je drvena kurija na čijoj je gredi bila urezana godina 1712. Kurija je srušena 1889. godine, a drvena je građa upotrijebljena za gradnju današnjeg dvorca. Dvorac Kulmer građen je u razdoblju od 1889. do 1890. godine po nacrtima inženjera Aleksandra Seća iz Zagreba.

Dvorac je izgrađen u duhu historicizma kao jednokatna građevina s dva krila u obliku slova "L" s poligonalnom dvokatnom kulom na spoju krila. U dvorac se ulazi sa sjeverne, "unutarnje" strane u čijem se prizemlju nalazi simetrično trokrako stubište s historicističkom ogradom od kovana željeza koje povezuje prizemlje i prvi kat. Prema izvorima za vrijeme Kulmera dvorac Bračak je u prizemlju i na katu imao 12 pravokutnih prostorija i 4 okrugle prostorije u kulama. Postojeći interijer dvorca izmijenjen je njegovom prenamjenom u bolnicu. Godinu izgradnje dvorca (1889.) možemo smatrati i godinom osnutka perivoja što potvrđuju podaci prilikom prvog upisa u zemljišne knjige iz 1886. godine gdje na današnjoj parceli perivoja stoji upisana oranica što znači da perivoj još nije postojao. Perivoj je podignut na površini od 3,38 hektara s jezerom površine $1.210 \mathrm{~m} 2$ uz postojeću šumu hrasta kitnjaka i običnog graba te se u njemu nalazio veći broj crnogoričnih stabala i egzotičnih vrsta. Posjedu Bračak pripadala je i šuma površine 100 hektara, oko 27 hektara oranica i livada te rijeka Krapina za iskorištavanje u dužini posjeda. Prema izvorima posjedu je također pripadala i "Oštarija grofova" s krčmom u najmu g. Hajdaša i mlin na Krapini.

Plemićki život u punom smislu te riječi vodio se na posjedu Bračak sve do poslije Drugog svjetskog rata, kada je 1947. godine grof Kulmer poklonio svoj posjed za liječenje djece oboljele od tuberkuloze 
Ivana Gašparović, Ž. Španjol, B. Dorbić, I. Tolić, Irena Milčić / Perivoj dvorca Kulmer-Bračak (Republika Hrvatska) - biološko i prostorno vrednovanje / Glasilo Future (2019) 2 (5-6) 01-23

pluća te je dvorac prenamijenjen u Dječju bolnicu za plućne bolesti. Izgradnjom nove županijske bolnice na susjednoj parceli 2008. godine bolnica je iseljena iz dvorca, a on napušten bez ikakve funkcije.

Katastarski plan Bračka iz 1902. godine (Slika 2.) jedini je kartografski prikaz koji nam daje uvid u prostornu kompoziciju i način organizacije objekata i prostora. Centar prostorne kompozicije čini dvorac okružen prostranim perivojem. Perivoj je ispresijecan krivudavim stazama koje su ga u cijelosti povezivale, a u dnu perivoja podno dvorca su vodile do jezera. Uz perivoj se na istočnoj strani nalazilo gospodarsko dvorište s nekoliko zgrada. Iz tlocrta se jasno čitaju pristupne ceste, tzv. "paradna" s istočne strane dvorca koja je prolazila kroz sam prostor perivoja dijeleći ga od gospodarskog dijela i "teretna" koja je sa sjevera zatvarala granicu perivoja i vodila do gospodarskih zgrada. S obzirom na grafiku može se prepoznati da su unutar perivoja sađene bjelogorične i crnogorične vrste drveća. U oblikovanju perivoja prevladava slobodni stil pod utjecajem engleskog krajobraznog stila što se čita iz postojećih staza i načina sadnje, dok ostali perivojno-arhitektonski elementi nisu poznati (ObadŠćitaroci, 1991; Čandrlić, 2005; Gregurić, 2009; Milčić, 2013).

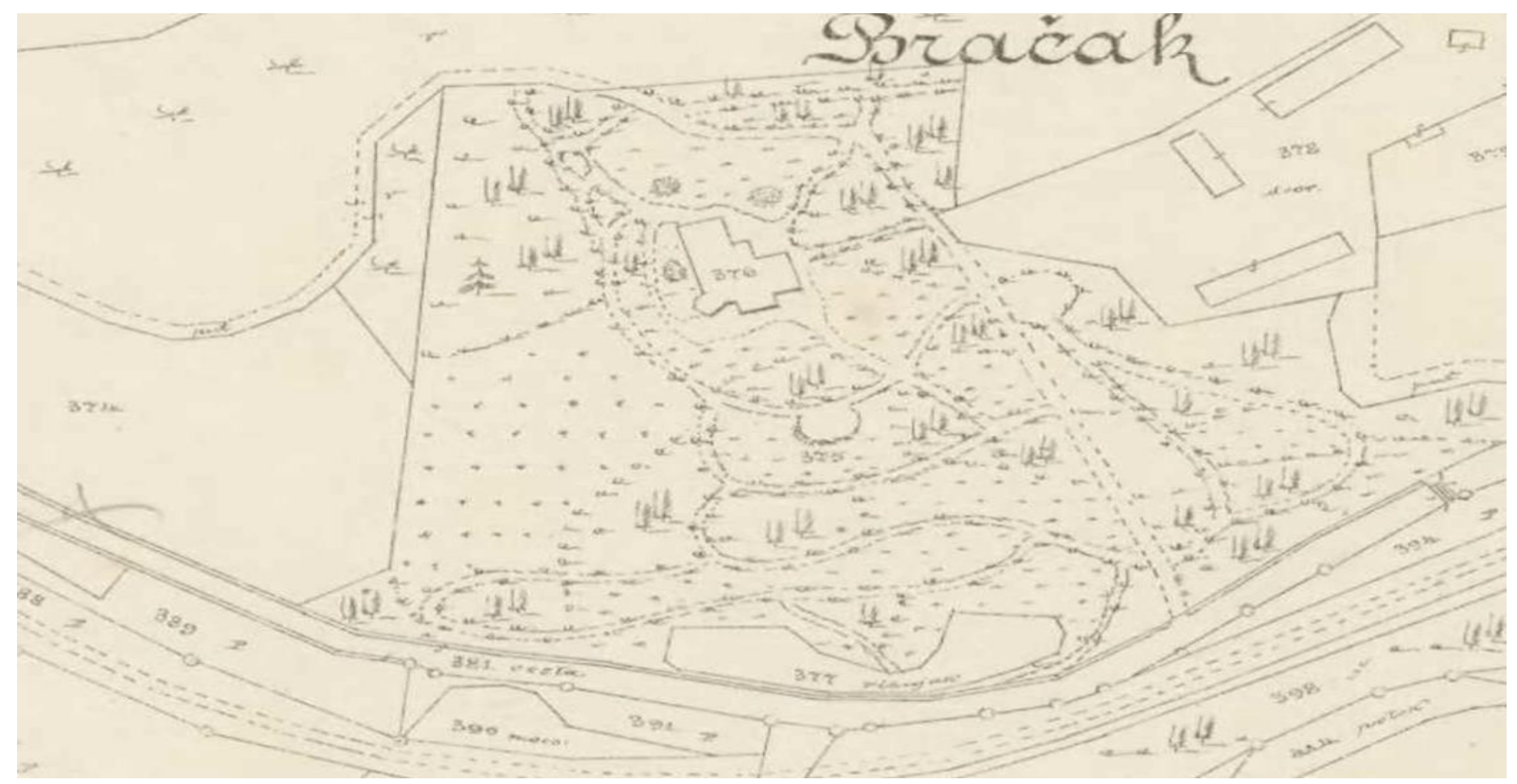

Slika 2. Detalj katastarskog plana iz 1902. godine (Izvor: Hrvatski državni arhiv, Fond 1421).

Figure 2. Detail of cadastral plan from 1902 (Source: Croatian State Archives, Fund 1421).

Uvidom u današnje stanje putem digitalnog ortofota preklopljenog s katastarskim planom čitamo prostornu kompoziciju te nastale promjene u odnosu na 1902. godinu (Slika 3).

$\mathrm{U}$ odnosu na prethodno analizirano razdoblje, prostor perivoja je umanjen u njegovom istočnom dijelu, a proširen u zapadnom dijelu. Granica perivoja s dvorcem sada je prostorno i funkcionalno određena cestama koje ga okružuju sa svih strana, tzv. "paradnom" i "teretnom" cestom kojima se i danas prilazi dvorcu i bolnici te lokalnom županijskom cestom s donje strane perivoja (Slike 3 i 4). 
Ivana Gašparović, Ž. Španjol, B. Dorbić, I. Tolić, Irena Milčić / Perivoj dvorca Kulmer-Bračak (Republika Hrvatska) - biološko i prostorno vrednovanje / Glasilo Future (2019) 2 (5-6) 01-23

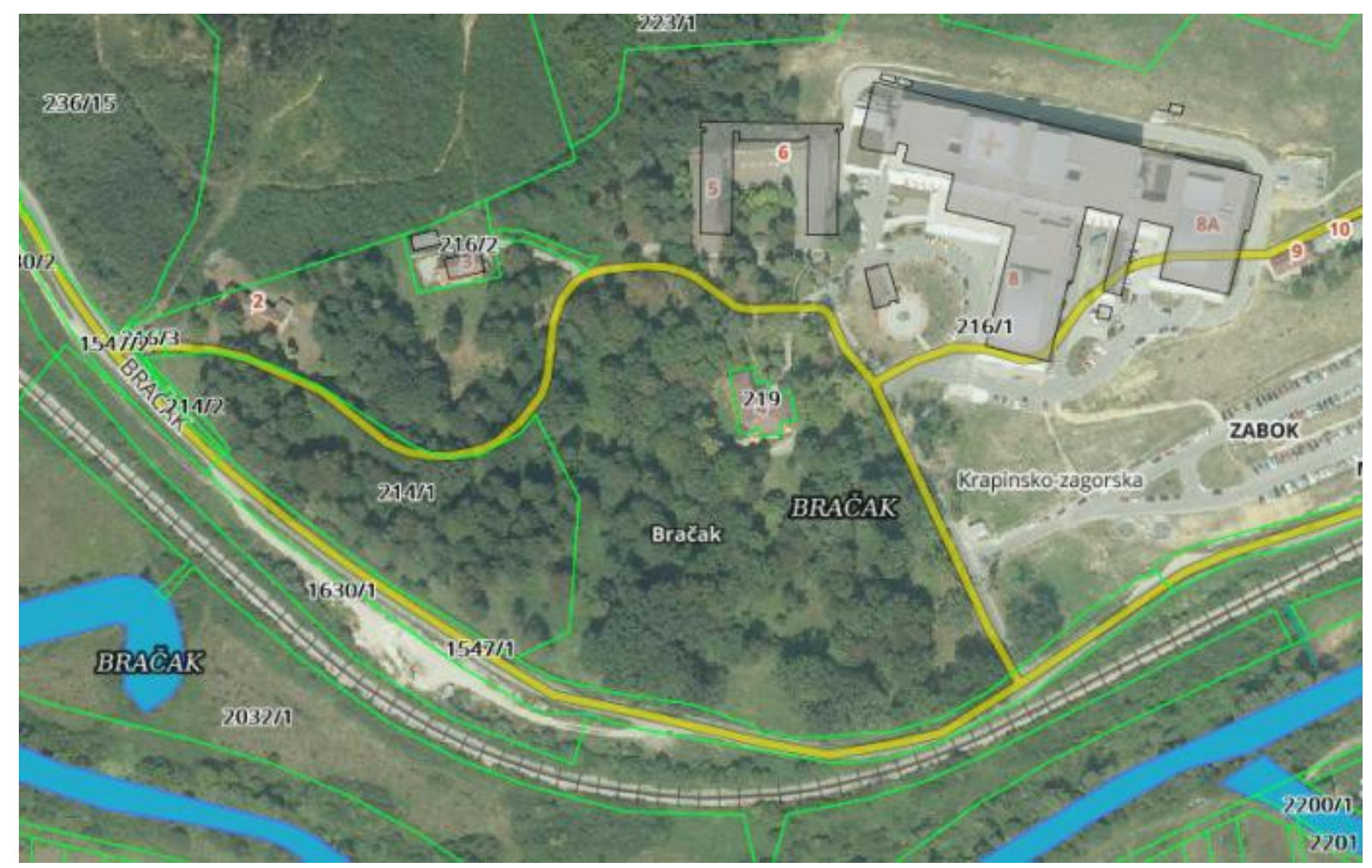

Slika 3. Digitalni ortofoto iz 2011. godine preklopljen s digitalnim katastarskim planom iz 2016. (prije nove parcelacije) (Izvor: Geoportal Državne geodetske uprave).

Figure 3. Digital orthophoto from 2011 overlaid with the digital cadastral plan from 2016 (before the new parcel) (Source: Geoportal of the State Geodetic Administration).

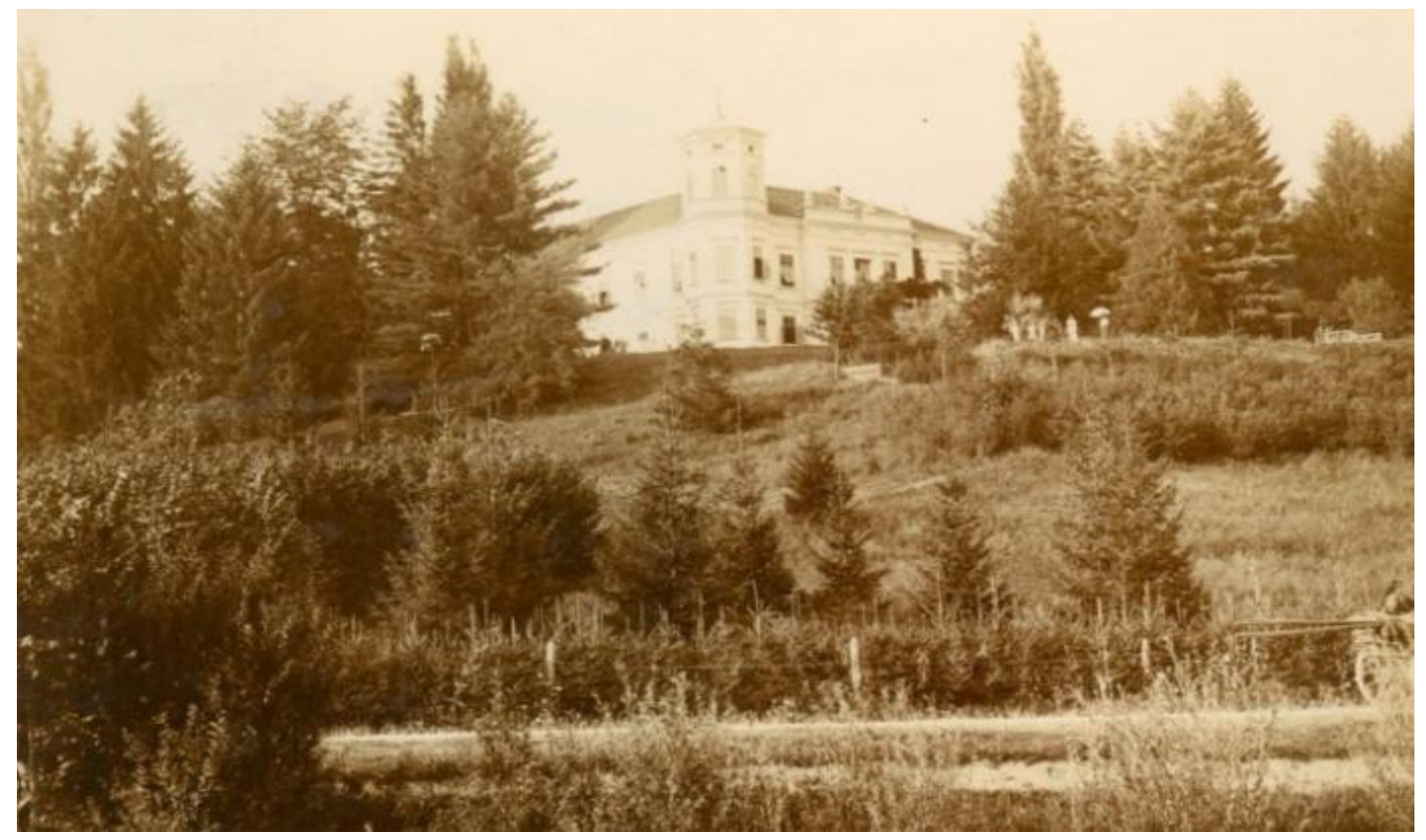

Slika 4. Pogled iz doline na dvorac Kulmer, početak 20. stoljeća (Izvor: Ministarstvo kulture, Konzervatorski odjel u Krapini).

Figure 4. View from the valley to Kulmer Castle, early $20^{\text {th }}$ century

(Source: Ministry of Culture, Conservation Department in Krapina). 


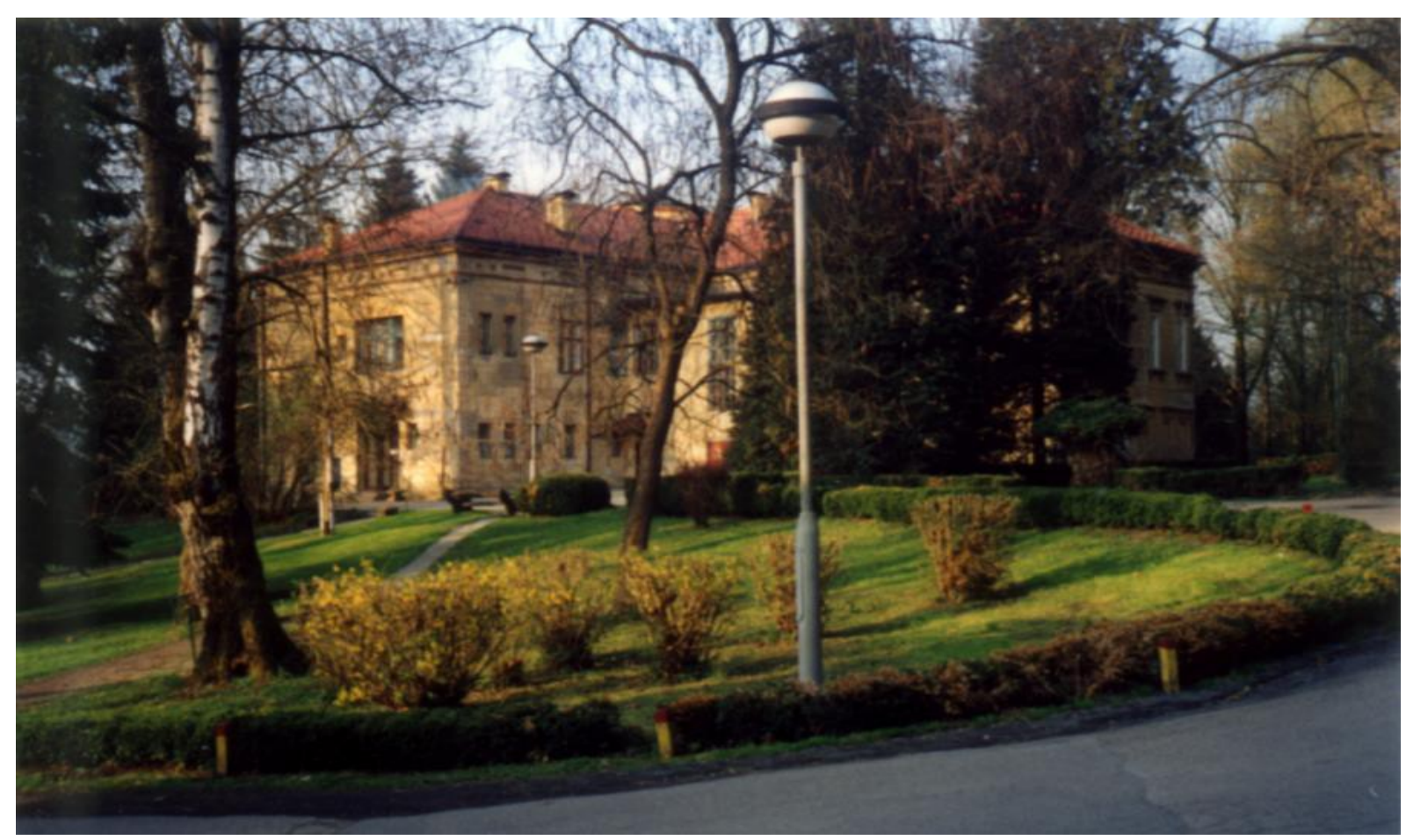

Slika 5. Pogled na sjeverno pročelje dvorca, ulazna strana (Foto: I. Milčić).

Figure 5. View of the north facade of the castle, entrance (Photo: I. Milčić).

\section{Karakteristike koncepcijske osnove perivoja}

Perivoj dvorca Kulmer, Bračak podignut je krajem 19. stoljeća kada je u stilskom oblikovanju širom Hrvatskog zagorja prevladavao engleski krajobrazni stil s obilježjima romantizma i historicizma. To je bilo stoljeće kada se grade objekti ladanjske arhitekture - dvorci, ljetnikovci i kurije, objekti koji daju osobito i osebujno obilježje Hrvatskom zagorju. Perivoj i dvorac oblikuju jedinstveni prostor u nedjeljivu cjelinu pokazujući rafiniran odnos prema postojećem krajobrazu. Krajobrazno oblikovani perivoji većih su površina, s nepravilnim stazama, a gotovo redovito uz dvorac dolaze i mali stilizirani parterni vrtovi ili gredice sa šišanim grmljem i raznobojnim cvijećem.

Perivoji su često nastajali iz samonikle šume ili uz nju, uz potok ili rijeku, na brijegu s prekrasnim vizurama na okolna polja, livade i šume, kakav je bio i perivoj dvorca Kulmer. To su perivoji koji zajedno s dvorcem dominiraju na vrhu brežuljka tako da se mogu lako uočiti iz okolnog prostora, a istodobno se iz perivoja pružaju lijepi vidici. Česti element perivoja bilo je i jezero koje je imalo dekorativno obilježje ili se koristilo kao ribnjak. Za perivoj Bračak nisu poznate osobite stilske karakteristike koje bi dale naslutiti obilježja romantizma i historicizma tipične za Hrvatsko zagorje toga vremena. Tada su uobičajeni bili perivoji s uređenim čistinama i jezerom čiji su sastavni elementi bile drvene bijele ograde i mostići na jezeru, antičke skulpture i hramovi, ruševine i grote te egzotične građevine i velik broj egzotičnog bilja. 
Ivana Gašparović, Ž. Španjol, B. Dorbić, I. Tolić, Irena Milčić / Perivoj dvorca Kulmer-Bračak (Republika Hrvatska) - biološko i prostorno vrednovanje / Glasilo Future (2019) 2 (5-6) 01-23

S obzirom na nedostatnu povijesnu građu koja se temelji na katastarskom planu iz 1902. godine i nekoliko starih fotografija i razglednica, na osnovu njihove analize i interpretacije dobiva se uvid u koncepcijsku osnovu iz tog razdoblja. Katastarski plan ukazuje na utjecaj engleskog krajobraznog stila i kompozicijsku osnovu sastavljenu od dvorca okruženog perivojem s jezerom i krivudavim stazama uz koje je podno dvorca bilo formirano i manje boravište. Uz sjeverno pročelje dvorca evidentirani su ostaci manjeg parternog vrta čije je konture moguće prepoznati iz ostataka kamenih rubnjaka u čijem središtu stoji element u obliku kamenog stupa ili postolja obrastao u bršljan. Čitamo ga također iz starih fotografija. Moguće razvojne etape i osobita stilska obilježja nisu poznata.

Za Bračak je na osnovu grafike i starih fotografija utvrđen i velik broj crnogoričnih vrsta drveća koje su sađene prilikom osnivanja perivoja, a koje su se kao alohtona vrsta intenzivno unosile u razdoblju 19. i 20. stoljeća te šišana živica koja je okruživala dvorac. Dvorac Kulmera ima kulturno-povijesnu vrijednost, a perivoj koji ga u cijelosti okružuje daje mu ambijentalnu vrijednost, ali bez osobitih stilskih obilježja. Prostor perivoja nije održavan u prvotnoj kompozicijskoj osnovi, nije istraživan niti valoriziran kroz proteklo razdoblje od njegove prenamjene, što je dovelo zone ugroženosti ne samo do samih granica perivoja već i unutar njega.

Gubitak identiteta perivoja Bračak događa se već dugi niz godina kao posljedica nedostatka neophodnih mjera održavanja, širenja bolničkog kompleksa i građevinskih zona što je uvjetovalo degradaciju prostora i gubitak prvotne kompozicijske osnove.

\section{Perivojno-arhitektonski elementi i stanje očuvanosti}

Istraživanja na prostoru perivoja provođena su tijekom 2011. i 2015. godine. Na prostoru perivoja od elemenata zatičemo nekoliko klupa, koševa i rasvjetnih stupova vjerojatno unesenih za vrijeme korištenja dvorca kao bolnice. Manji parterni vrt uz dvorac, koji je istraživanjem 2011. godine još uvijek bilo moguće prepoznati, 2015. godine je gotovo uništen uslijed radova na obnovi dvorca. Uz južnu fasadu dvorca na prijelazu u perivoj pronađeni su ostaci tri kamena postolja. Južno od dvorca prepoznajemo ostatke manjeg polukružnog boravišta okruženog živicom od šimšira do kog vode stepenice, a koje se čita i iz katastarskog plana iz 1902. godine. Iz prostora perivoja nestali su jezero i staze koje također čitamo na katastarskom planu iz 1902. godine. Preostale komunikacije se prepoznaju na samom prostoru oko dvorca kroz ostatke sipine, dok je sam ulaz popločan betonskim pločama, a prilazne ceste su asfaltirane. Unutar perivoja zatičemo i dva objekta koji su danas izvan funkcije, a nekada u funkciji sabirne jame s pripadajućim kanalizacijskim cijevima te prepumpne stanice. Za iste je predviđeno njihovo uklanjanje.

Kako je to već bilo uobičajeno u kasnijoj vrtnoj arhitekturi tako i u Bračku početkom 20. stoljeća perivoj obiluje autohtonim, ali i raznolikim alohtonim biljem, posebice četinjačama o čemu nam svjedoče fotografije. Postojeći biljni materijal koji i danas zatičemo datira upravo iz tog vremena. 
Ivana Gašparović, Ž. Španjol, B. Dorbić, I. Tolić, Irena Milčić / Perivoj dvorca Kulmer-Bračak (Republika Hrvatska) - biološko i prostorno vrednovanje / Glasilo Future (2019) 2 (5-6) 01-23

Budući da je "građevni materijal" objekata perivojne arhitekture živ i nepostojan, izložen je procesima s nizom kontinuiranih promjena. Iz tog razloga perivojnu arhitekturu treba promatrati u prostoru i vremenu jer se slika neprestano mijenja pa perivoji rijetko kada nalikuju na kompozicije na kojima su osnovani. Tako danas zatičemo perivoj koji je zbog nedostatnog održavanja u fazi prirodne sukcesije s brojnim podrastima, sušcima, izvaljenim stablima i jedinkama lošeg zdravstvenog stanja s obzirom da su dosegle svoju fiziološku zrelost ili su neprimjereno održavane. Sukladno navedenom perivoj danas svojim izgledom više podsjeća na neprohodnu šumu, nego na perivoj što estetski narušava sveukupni dojam. Također zatičemo ostatke živice od šimšira koja je još 2011. godine uokvirivala prostor oko dvorca, a koja se zbog bolesti potpuno osušila i uklonila. Miješana živica je mjestimično zatečena i u rubnim dijelovima perivoja uz postojeće ceste koje ga okružuju, a ista je tijekom 2015. godine u gornjem dijelu gotovo uništena uslijed čišćenja.

Iz postojećeg stanja je evidentno da perivoj već dugi niz godina nema nikakvu funkciju niti su se provodile neophodne mjere njege, osim najosnovnijeg održavanja. Usporedbom terenskih istraživanja iz 2011. godine i 2015. godine dobiva se uvid u pojedine elemente i sadržaje unutar perivoja, sastav dendroflore i naposljetku brzinu degradacije prostora perivoja zbog njegovog neodržavanja, posebno kada govorimo o dendroflori.

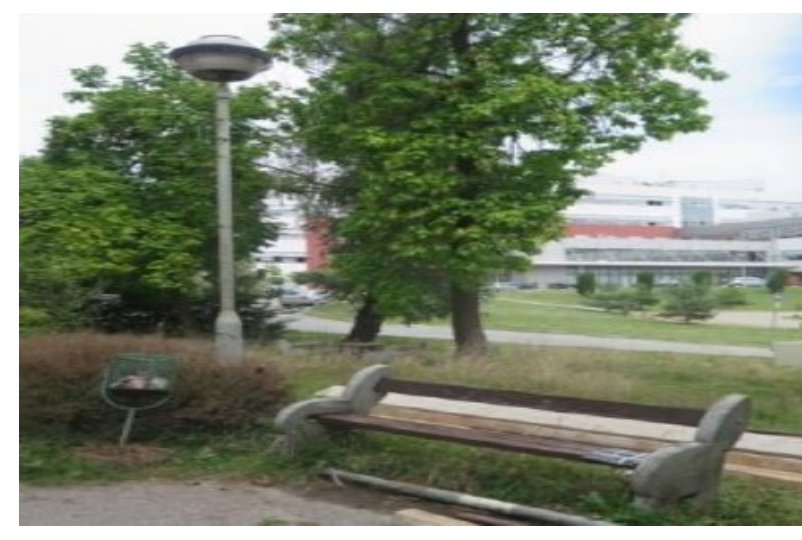

Slika 6. Prikaz postojećih perivojnih klupa (Foto: I. Gašparović).

Figure 6. View of existing park benches (Photo: I. Gašparović).

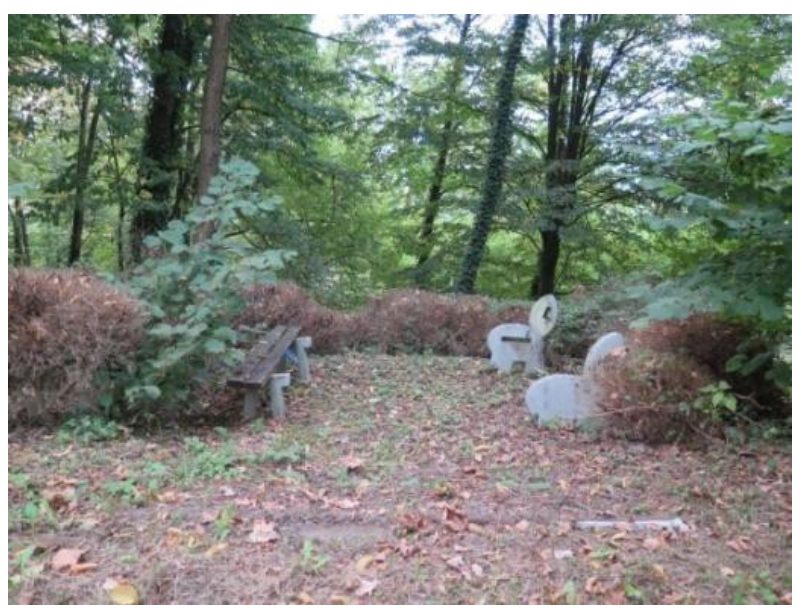

Slika 7. Sušenje živice ispod dvorca (Foto: I. Gašparović).

Figure 7. Hedge drying under the castle (Photo: I. Gašparović). 
Ivana Gašparović, Ž. Španjol, B. Dorbić, I. Tolić, Irena Milčić / Perivoj dvorca Kulmer-Bračak (Republika Hrvatska) - biološko i prostorno vrednovanje / Glasilo Future (2019) 2 (5-6) 01-23

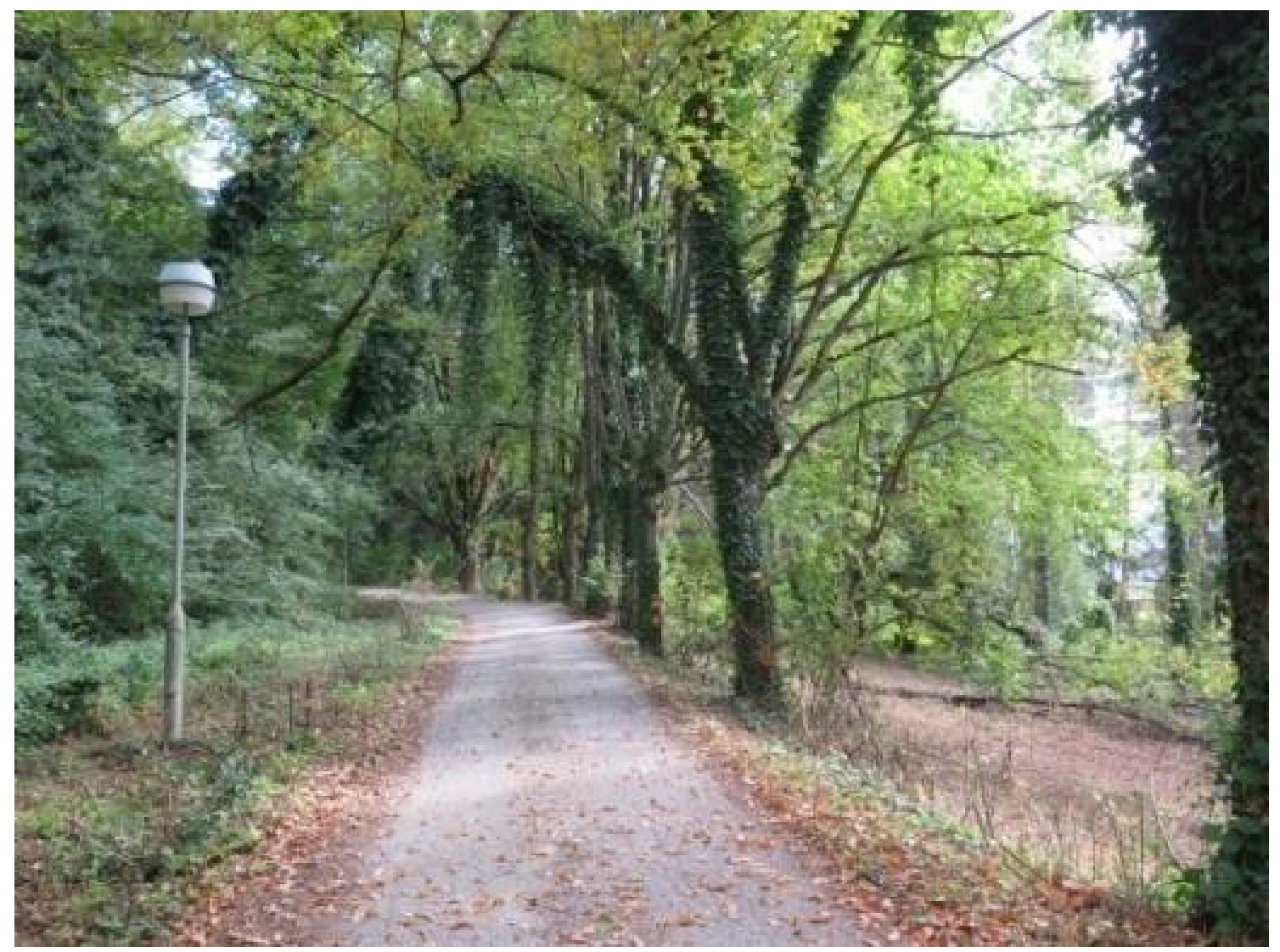

Slika 8. Ostaci drvoreda uz cestu koja okružuje perivoj (Foto: I. Gašparović).

Figure 8. The remains of the avenue along the road surrounding the park (Photo: I. Gašparović).

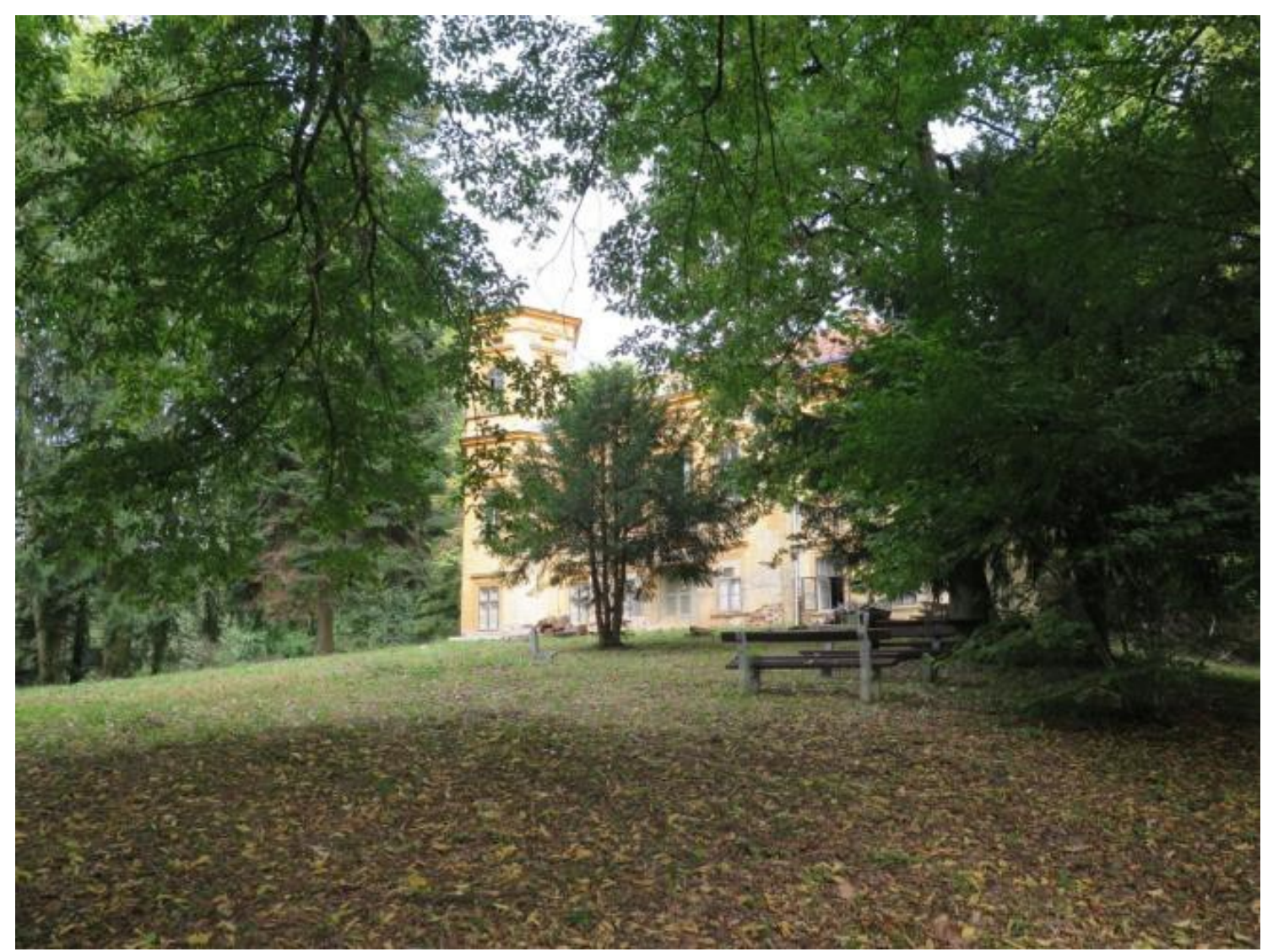

Slika 9. Donekle održavan prostor oko dvorca (Foto: I. Gašparović).

Figure 9. Somewhat maintained space around the castle (Photo: I. Gašparović). 
Ivana Gašparović, Ž. Španjol, B. Dorbić, I. Tolić, Irena Milčić / Perivoj dvorca Kulmer-Bračak (Republika Hrvatska) - biološko i prostorno vrednovanje / Glasilo Future (2019) 2 (5-6) 01-23

\section{Dendroflora na području perivoja}

Perivoj Bračak se u vegetacijskom smislu nalazi na spoju mezofilnih, više ili manje neutrofilnih šuma hrasta lužnjaka (Quercus robur L.) i hrasta kitnjaka (Quercus petrae L.) s običnim grabom (Carpinus betulus L.) koje rastu u nizinskom i brežuljkastom pojasu većeg dijela sjeverne Hrvatske i susjednih područja na visinama od 120 do $400 \mathrm{~m}$. Temeljne i najzastupljenije šumske zajednica su šuma hrasta lužnjaka i običnog graba (Carpino betuli-Quercetum roboris (Anić, 1959; Rauš, 1971)) te ilirska šuma hrasta kitnjaka i običnog graba s biskupskom kapicom (Epimedio-Carpinetum betuli (Horvat, 1938; Borhidi, 1963)), u prijašnjoj literaturi navođena kao Querco-Carpinetum croaticum (Horvat, 1938).

Uslijed nedostatka podataka o biljnom sastavu kroz povijest perivoja i uzmemo li u obzir činjenicu da je utilitarna funkcija posjeda nadilazila reprezentativnu, možemo zaključiti da su prevladavale pretežno autohtone vrste, hrast lužnjak (Quercus robur L.), obični grab (Carpinus butulus L.), poljski javor ili klen (Acer campestre L.), malolisna lipa (Tilia cordata Mill.), poljski jasen (Fraxinus angustifolia Vahl.), poljski brijest (Ulmus minor Mil.), javor mliječ (Acer platanoides L.) i druge autohtone vrste. Početkom 20. stoljeća su se u perivojima Hrvatskog zagorja osim autohtone vegetacije mogli naći još i divlji kesten (Aesculus hippocastanum L.), javorolisna platana (Platanus $\mathrm{x}$ acerifolia (Aiton) Willd.), bukva (Fagus sylvatica L.), tulipanovac (Liriodendron tulipifera L.), breza (Betula pendula Roth.), katalpa (Catalpa bignonioides Walter), obična smreka (Picea abies (L.) Karsten), obični ili bijeli bor (Pinus sylvestris L.), zatim uz jezero crna topola ili jablan (Populus nigra L.) i žalosna vrba (Salix babylonica L.) te druge vrste specifične za zagorske perivoje (Vukelić, 2012). Većinu također možemo pronaći i u perivoju Bračak.

Kako je to već bilo uobičajeno u kasnoj romantičarskoj i historicističkoj vrtnoj arhitekturi, potkraj 19. i početkom 20. stoljeća perivoj obiluje i raznolikim alohtonim biljem, osobito crnogoricom i egzotama koje su se tada intenzivno sadile i uzgajale. O postojanju egzotičnih vrsta svjedoče jedino zapisi.

Istraživanjima 2011. i 2015. godine u perivoju je evidentirano 28 vrsta drveća i grmlja listača te 9 vrsta četinjača (Tablice 1. i 2.)

Unutar perivoja u zoni obuhvata inventarizacijama (Tablica 1. i 2.) je zatečeno ukupno 738 jedinki kao perivojnih elemenata drveća i višeg grmlja iz 37 vrsta, od čega 9 vrsta četinjača s 221 i 28 vrsta listača s 517 jedinki. Iz tablice je uočljivo da su najzastupljenije vrste listača bagrem (Robinia pseudoacacia L.), hrast lužnjak (Quercus robur L.), malolisna lipa (Tilia cordata Mill.) i obični grab (Carpinus betulus L.), što potvrđuje utvrđenu analizu vegetacijskog razvoja i prepuštanje perivoja nebrizi i prirodnoj sukcesiji. Hrast lužnjak, kao najstarija vrsta, a time i najvećih promjera, zastupljen je u gotovo svim debljinskim razredima. Značajnijih dimenzija imamo i pokoju platanu (Platanus $x$ hispanica Münchh.) i malolisnu lipu te jedan primjerak pitomog kestena (Castanea sativa L.).

Od četinjača najzastupljeniji su obična smreka (Picea abies (L.) Karsten) i crni bor (Pinus nigra J. F. Arnold). 
Ivana Gašparović, Ž. Španjol, B. Dorbić, I. Tolić, Irena Milčić / Perivoj dvorca Kulmer-Bračak (Republika Hrvatska) - biološko i prostorno vrednovanje / Glasilo Future (2019) 2 (5-6) 01-23

Od grmlja na prostoru perivoja zatičemo šimšir (Buxus sempervirens L.), obični grab (Carpinus betulus L.), klen (Acer campestre L.) i ligustrum (Ligustrum vulgare L.) i to u obliku živice. Pojedinačno grmlje kao perivojni element nije zabilježeno. Kako je perivoj zadnjih desetljeća bio prepušten spontanom razvoju i samo djelomičnom provođenju osnovnih mjera njege i održavanja, u njemu je zatečena uznapredovala sukcesija autohtone, klimazonalne vegetacije kao i spontano širenje pojedinih alohtonih vrsta kao pionirskih. Vegetacija je vrlo gusta i gotovo neprohodna. U inicijalnoj sukcesiji autohtone vegetacije u sloju ponika i mlađeg pomlatka najzastupljeniji su hrast lužnjak (Quercus robur L.), obični grab (Carpinus betulus L.) i obična bukva (Fagus sylvatica L.).

Od alohtonih vrsta u sloju pomlatka najzastupljeniji je divlji kesten (Aesculus hippocastanum L.). Isprepliće se gusti sloj prizemnog zeljastog rašća sa nižim grmljem od 2 do $4 \mathrm{~m}$ tako da je vizura unutar perivoja gotovo zatvorena. Najzastupljenija vrsta u perivoju u sloju nižeg grmlja svakako je kupina (Rubus fruticosus L.) koja se rasprostire gotovo kroz čitav perivoj na visini od 0,50 do $0,80 \mathrm{~m} \mathrm{i}$ čini ga gotovo neprohodnim dok je u nižem vlažnijem dijelu perivoja dominantna preslica (Equisetum sp.) visine od 0,60 do $1,00 \mathrm{~m}$. Tako u velikim skupinama $\mathrm{u}$ sloju visokog grmlja kao podrast $\mathrm{u}$ najvećem broju zatičemo bagrem (Robinia pseudoacacia L.), brezu (Betula pendula Roth.) i lijesku (Corylus avellana L.), zatim klen (Acer campestre L.), gorski javor (Acer pseudoplatanus L.), obični grab (Carpinus betulus L.), poljski jasen (Fraxinus angustifolia Vahl.), gorski brijest (Ulmus glabra Huds.), malolisnu lipu (Tilia cordata Mill.), divlju trešnju (Prunus avium L.), vrbu ivu (Salix caprea L.), crvenu hudiku (Viburnum opulus L.), kuriku (Euonymus europaeus L.) i druge. Od alohtonih penjačica uobičajenih u perivojima Hrvatskog zagorja na prostoru Bračka zatičemo peterolisnu lozicu (Partenocissus quinqefolia (L.) Planch) koja se spontano, ali intenzivno širi te čini niži sloj grmlja do $0,70 \mathrm{~m}$ te se zajedno sa bršljanom penje na visoka stabla i preko $20 \mathrm{~m}$ visine. Kao specifičnost na prostoru perivoja u sloju grmlja u većim grupama je zatečena vrsta otrovni bršljan (Toxicodendron radicans (L.) Kuntze) također kao posljedica neodržavanja perivoja. U najnižim dijelovima perivoja, gdje se povremeno zadržava voda koja uvjetuje vlažno stanište, zabilježene su perunike (Iris pseudacorus L.).

Tablica 1. Inventarizacija dendroflore listača sa sušcima 2011. i 2015. g., perivoj Bračak.

Table 1. Inventory of deciduous trees with dead stumps 2011 and 2015 y., public garden Bračak.

\begin{tabular}{|c|c|c|c|c|c|c|c|c|c|c|c|c|c|c|c|c|c|c|}
\hline \multicolumn{2}{|l|}{ Vrsta } & \multicolumn{16}{|c|}{ Broj stabala po debljinskim razredima u cm } & \multirow[b]{2}{*}{$\sum$} \\
\hline Latinski naziv & $\begin{array}{c}\text { Hrvatski } \\
\text { naziv }\end{array}$ & $\stackrel{9}{I}$ & $\begin{array}{l}\text { ิㅗ } \\
\text { I }\end{array}$ & 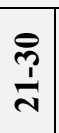 & $\frac{P}{\dot{m}}$ & $\frac{8}{7}$ & $\frac{8}{10}$ & $\frac{7}{1}$ & $\begin{array}{l}\stackrel{0}{\infty} \\
\frac{1}{1}\end{array}$ & $\frac{a}{\infty}$ & $\frac{8}{\frac{1}{2}}$ & $\begin{array}{l}\stackrel{\Theta}{\Xi} \\
\frac{1}{\Theta}\end{array}$ & $\begin{array}{l}\stackrel{\Xi}{\Xi} \\
\Xi \\
\Xi\end{array}$ & $\frac{P}{\stackrel{m}{I}}$ & $\frac{P}{\frac{1}{2}}$ & $\begin{array}{l}\frac{8}{2} \\
\frac{1}{ \pm}\end{array}$ & $\begin{array}{l}\frac{8}{0} \\
\frac{1}{n}\end{array}$ & \\
\hline Acer campestre $\mathrm{L}$. & klen & 8 & 8 & 7 & 6 & 2 & 1 & & 1 & & & & & & & & & 33 \\
\hline Acer negundo L. & $\begin{array}{c}\text { javor } \\
\text { negundovac }\end{array}$ & 3 & 1 & 1 & & & 1 & & & & & & & & & & & 6 \\
\hline Acer platanoides $\mathrm{L}$. & javor mliječ & 8 & 1 & & & & & & & & & & & & & & & 9 \\
\hline Acer pseudoplatanus $\mathrm{L}$. & gorski javor & & & 3 & 1 & & & & & & & & & & & & & 4 \\
\hline Acer saccharinum $\mathrm{L}$. & $\begin{array}{c}\text { srebrnolisni } \\
\text { javor }\end{array}$ & 1 & 2 & 3 & & & & & & & & & & & & & & 6 \\
\hline
\end{tabular}


Ivana Gašparović, Ž. Španjol, B. Dorbić, I. Tolić, Irena Milčić / Perivoj dvorca Kulmer-Bračak (Republika Hrvatska) - biološko i prostorno vrednovanje / Glasilo Future (2019) 2 (5-6) 01-23

\begin{tabular}{|c|c|c|c|c|c|c|c|c|c|c|c|c|c|c|c|c|c|c|}
\hline \multicolumn{2}{|l|}{ Vrsta } & \multicolumn{16}{|c|}{ Broj stabala po debljinskim razredima u cm } & \multirow[b]{2}{*}{$\sum$} \\
\hline Latinski naziv & $\begin{array}{l}\text { Hrvatski } \\
\text { naziv }\end{array}$ & $\stackrel{ }{I}$ & 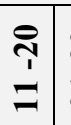 & $\frac{\vec{r}}{\vec{r}}$ & $\frac{P}{\frac{9}{m}}$ & $\frac{8}{10}$ & $\begin{array}{l}8 \\
\frac{1}{n}\end{array}$ & $\frac{R}{\frac{1}{6}}$ & 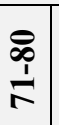 & \begin{tabular}{l|l}
\multirow{1}{\infty}{} \\
$\infty$
\end{tabular} & $\frac{8}{\frac{1}{a}}$ & 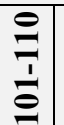 & $\begin{array}{l}\stackrel{\Xi}{\mathbb{I}} \\
\stackrel{I}{\Xi} \\
\Xi\end{array}$ & $\begin{array}{l}\stackrel{m}{I} \\
\frac{1}{\beth}\end{array}$ & \begin{tabular}{l|}
$\frac{9}{T}$ \\
$\frac{1}{2}$
\end{tabular} & $\begin{array}{l}\frac{1}{1} \\
\frac{1}{7} \\
\end{array}$ & $\begin{array}{l}\frac{8}{1} \\
\frac{1}{n}\end{array}$ & \\
\hline Aesculus hippocastanum L. & divlji kesten & 9 & 22 & 12 & & & & & & 1 & & & & & & & & 44 \\
\hline Betula pendula Roth & obična breza & & 1 & 4 & 15 & 2 & 2 & 1 & & & & & & & & & & 25 \\
\hline Carpinus betulus L. & obični grab & & 9 & 9 & 16 & 4 & 6 & 1 & & & & & & & & & & 45 \\
\hline Castanea sativa $\mathrm{L}$. & pitomi kesten & & & & & & & & & & & & 1 & & & & & 1 \\
\hline Catalpa bignonioides Walter & katalpa & 1 & 3 & 1 & 2 & 2 & 1 & & & & & & & & & & & 10 \\
\hline Corylus avellana $\mathrm{L}$. & obična lijeska & 7 & 3 & & & & & & & & & & & & & & & 10 \\
\hline $\begin{array}{c}\text { Fraxinus angustifolia } \\
\text { Vahl }\end{array}$ & poljski jasen & 2 & & 1 & & & 3 & & & & & & & & & & & 6 \\
\hline Gleditchia triacanthos L. & trnovac & & & & & 1 & & & & & & & & & & & 1 & 2 \\
\hline Juglansnigra $\mathrm{L}$. & crni orah & 1 & & & & & & & & & & & & & & & & 1 \\
\hline Juglans regia $\mathrm{L}$. & pitomi orah & 1 & & & & & & & & & & & & & & & & 1 \\
\hline Malus domestica Borkh. & jabuka & & & 2 & & & & & & & & & & & & & & 2 \\
\hline Morus alba $\mathrm{L}$. & bijeli dud & & & 1 & & & & & & & & & & & & & & 1 \\
\hline $\begin{array}{c}\text { Platanus } x \text { hispanica } \\
\text { Münchh. }\end{array}$ & $\begin{array}{c}\text { javoro } \\
\text { lisna platana }\end{array}$ & & & & 1 & 4 & & 2 & 1 & 1 & & 2 & & & & & & 11 \\
\hline Prunus avium L. & trešnja & 1 & 1 & & & 2 & 1 & 1 & & & & & & & & & & 6 \\
\hline Prunus spinosa $\mathrm{L}$. & crni trn & 1 & & & & & & & & & & & & & & & & 1 \\
\hline Pyruscommunis L. & kruška & & & & 4 & 5 & & & & & & & & & & & & 9 \\
\hline Quercus robur $\mathrm{L}$. & hrast lužnjak & & 3 & 2 & 14 & 12 & 18 & 14 & 9 & 9 & & 4 & 2 & 1 & & 1 & & 89 \\
\hline Robinia pseudoacacia $\mathrm{L}$. & $\begin{array}{c}\text { obični } \\
\text { bagrem }\end{array}$ & 89 & 13 & 1 & 1 & 1 & & 1 & & & & & & & & & & 106 \\
\hline Salix alba $\mathrm{L}$. & bijela vrba & & 1 & & & & & & & & & & & & & & & 1 \\
\hline Sorbus torminalis L. & brekinja & & & & & 1 & & & & & & & & & & & & 1 \\
\hline Tilia cordata Mill. & malolisna lipa & 9 & 5 & 13 & 13 & 15 & 12 & 4 & 3 & & & & & & & & & 74 \\
\hline Ulmus glabra Huds. & gorski brijest & 5 & 1 & 1 & 1 & 1 & & 1 & & & & & & & & & & 10 \\
\hline Ulmus minor Mill. & poljski brijest & & 2 & & & & 1 & & & & & & & & & & & 3 \\
\hline Ukupno & & 146 & \begin{tabular}{l|l}
76 & 1 \\
\end{tabular} & 61 & 74 & 52 & 46 & 25 & 14 & 11 & & 6 & 3 & 1 & & 1 & 1 & 517 \\
\hline
\end{tabular}

Tablica 2. Inventarizacija dendroflore četinjača sa sušcima 2011. i 2015. g., perivoj Bračak.

Table 2. Inventory of conifers dendroflora with dead stumps 2011 and 2015 y., public garden Bračak.

\begin{tabular}{|c|c|c|c|c|c|c|c|c|c|c|c|c|}
\hline \multicolumn{2}{|l|}{ Vrsta } & \multicolumn{10}{|c|}{ Broj stabala po debljinskim razredima u cm } & \multirow[b]{2}{*}{$\sum$} \\
\hline Latinski naziv & Hrvatski naziv & $\stackrel{9}{I}$ & $\stackrel{\text { ป }}{\beth}$ & 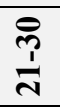 & $\frac{9}{i}$ & $\underset{7}{8}$ & $\begin{array}{l}8 \\
\frac{1}{n}\end{array}$ & $\frac{R}{6}$ & $\begin{array}{l}\infty \\
\stackrel{1}{1} \\
\end{array}$ & $\frac{a}{\infty}$ & $\frac{1}{2}$ & \\
\hline Abies alba Mill. & obična jela & & 2 & 5 & 2 & 1 & 2 & & & & & 12 \\
\hline $\begin{array}{c}\text { Abies nordmanniana (Steven) } \\
\text { Spach }\end{array}$ & kavkaska jela & & & & & 1 & 1 & & & & & 2 \\
\hline $\begin{array}{l}\text { Chamaecyparis lawsoniana } \\
\text { (A. Murray) Parl. }\end{array}$ & $\begin{array}{l}\text { lawsonov } \\
\text { pačempres }\end{array}$ & & 5 & 4 & 6 & & & & & & & 15 \\
\hline $\begin{array}{l}\text { Cryptomeria japonica (L. f.) D. } \\
\text { Don. }\end{array}$ & $\begin{array}{c}\text { japanska } \\
\text { kriptomerija }\end{array}$ & & & 1 & & & & & & & & 1 \\
\hline Larixdecidua Mill. & europski ariš & & 2 & & 1 & & & & & & & 3 \\
\hline Picea abies (L.) Karsten & obična smreka & 3 & 2 & 13 & 15 & 42 & 28 & 10 & 1 & 4 & 1 & 119 \\
\hline Pinus nigra J. F. Arnold & crni bor & 1 & 2 & 7 & 19 & 11 & 1 & & & & & 41 \\
\hline Pinus sylvestris $\mathrm{L}$. & bijeli bor & & & & 5 & 9 & 1 & 1 & & & & 16 \\
\hline Taxus baccata L. & obična tisa & 2 & 2 & 1 & 3 & 2 & 1 & 1 & & & & 12 \\
\hline \multicolumn{2}{|l|}{ Ukupno } & 6 & 15 & 31 & 51 & 66 & 34 & 12 & 1 & 4 & 1 & 221 \\
\hline
\end{tabular}


Ivana Gašparović, Ž. Španjol, B. Dorbić, I. Tolić, Irena Milčić / Perivoj dvorca Kulmer-Bračak (Republika Hrvatska) - biološko i prostorno vrednovanje / Glasilo Future (2019) 2 (5-6) 01-23

Evidencijom zdravstvenog stanja (Tablice 3. i 4.) uočljivo je da kod listača više od polovice stabala nema oštećenost dok ih je u stupnju 2. 167, u 3. 48, a sušaca 20. Hrast lužnjak (Quercus robur L.) s obzirom na starost i dimenzije je najlošijeg stanja, zatim malolisna lipa (Tilia cordata Mill.). Kod četinjača više od polovice stabala je znatno oštećeno. Tako je u stupnju 2. 51, u stupnju 3. 11, a sušaca je 55 stabala. Iz tablice je uočljivo intenzivno sušenje smreke (Picea abies (L.) Karsten) te značajno crnog bora (Pinus nigra J. F. Arnold.). Sukladno provedenoj inventarizaciji i analizi kojom je utvrđena uznapredovala sukcesija autohtone vegetacije i spontano širenje pojedinih alohtonih vrsta te velik broj sušaca, izvaljenih ili polomljenih stabala i panjeva uslijed zapuštenosti perivoja donesen je zaključak o njegovom vrlo lošem zdravstvenom i estetskom stanju.

Tablica 3. Oštećenost stabala listača 2011. i 2015. g., perivoj Bračak.

Table 3. Deciduous trees damages in 2011 and 2015 y. in the public garden Bračak.

\begin{tabular}{|c|c|c|c|c|c|c|}
\hline \multicolumn{2}{|l|}{ Vrsta } & \multicolumn{5}{|c|}{ OŠTEĆENJA ( broj stabala) } \\
\hline Latinski naziv & Hrvatski naziv & $\begin{array}{c}1 \\
\text { nije } \\
\text { oštećeno }\end{array}$ & $\begin{array}{c}2 \\
\text { oštećeno }\end{array}$ & $\begin{array}{c}3 \\
\text { dosta } \\
\text { oštećeno }\end{array}$ & SUŠCI & $\Sigma$ \\
\hline Acer campestre $\mathrm{L}$. & klen & 25 & 6 & 2 & & 33 \\
\hline Acer negundo L. & javor negundovac & 4 & 1 & & 1 & 6 \\
\hline Acer platanoides $\mathrm{L}$. & javor mliječ & 9 & & & & 9 \\
\hline Acer pseudoplatanus L. & gorski javor & 2 & 1 & 1 & & 4 \\
\hline Acer saccharinum L. & srebrnolisni javor & 6 & & & & 6 \\
\hline Aesculus hippocastanum L. & divlji kesten & 1 & 42 & 1 & & 44 \\
\hline Betula pendula Roth & obična breza & 5 & 14 & 2 & 4 & 25 \\
\hline Carpinus betulus L. & obični grab & 31 & 7 & 2 & 5 & 45 \\
\hline Castanea sativa $\mathrm{L}$. & pitomi kesten & & & 1 & & 1 \\
\hline Catalpa bignonioides Walter & katalpa & 4 & 4 & 2 & & 10 \\
\hline Corylus avellana $\mathrm{L}$. & obična lijeska & 10 & & & & 10 \\
\hline Fraxinus angustifolia Vahl & poljski jasen & 2 & 3 & 1 & & 6 \\
\hline Gleditchia triacanthos L. & trnovac & & & 1 & 1 & 2 \\
\hline Juglans nigra L. & crni orah & & & 1 & & 1 \\
\hline Juglans regia $\mathrm{L}$. & pitomi orah & 1 & & & & 1 \\
\hline Malus domestica Borkh. & jabuka & & & 2 & & 2 \\
\hline Morus alba $\mathrm{L}$. & bijeli dud & & & 1 & & 1 \\
\hline Platanus $x$ hispanica Münchh. & javorolisna platana & 8 & 2 & 1 & & 11 \\
\hline Prunus avium $\mathrm{L}$. & trešnja & 3 & 1 & 2 & & 6 \\
\hline Prunus spinosa $\mathrm{L}$. & crni trn & 1 & & & & 1 \\
\hline Pyruscommunis L. & kruška & & 9 & & & 9 \\
\hline Quercus robur $\mathrm{L}$. & hrast lužnjak & 15 & 49 & 23 & 2 & 89 \\
\hline Robinia pseudoacacia L. & obični bagrem & 102 & 3 & 1 & & 106 \\
\hline Salix alba $\mathrm{L}$ & bijela vrba & 1 & & & & 1 \\
\hline Sorbus torminalis $\mathrm{L}$. & brekinja & 1 & & & & 1 \\
\hline Tilia cordata Mill. & sitnolisna lipa & 42 & 25 & 3 & 4 & 74 \\
\hline Ulmus glabra Huds. & gorski brijest & 7 & & & 3 & 10 \\
\hline Ulmus minor Mill. & poljski brijest & 2 & & 1 & & 3 \\
\hline \multicolumn{2}{|l|}{ Ukupno } & 282 & 167 & 48 & 20 & 517 \\
\hline
\end{tabular}


Ivana Gašparović, Ž. Španjol, B. Dorbić, I. Tolić, Irena Milčić / Perivoj dvorca Kulmer-Bračak (Republika Hrvatska) - biološko i prostorno vrednovanje / Glasilo Future (2019) 2 (5-6) 01-23

Tablica 4. Oštećenost stabala četinjača 2011. i 2015. g., perivoj Bračak.

Table 4. Conifers damage in 2011 and 2015 y. in the public garden Bračak.

\begin{tabular}{|c|c|c|c|c|c|c|}
\hline \multicolumn{2}{|c|}{ Vrsta } & \multicolumn{5}{c|}{ OŠTEĆENJA (broj stabala) } \\
\hline Latinski naziv & Hrvatski naziv & $\begin{array}{c}\mathbf{1} \\
\text { nije } \\
\text { oštećeno }\end{array}$ & $\begin{array}{c}\mathbf{2} \\
\text { Oštećeno }\end{array}$ & $\begin{array}{c}\mathbf{3} \\
\text { dosta } \\
\text { oštećeno }\end{array}$ & SUŠCI & $\Sigma$ \\
\hline Abies alba Mill. & obična jela & 11 & & & 1 & 12 \\
\hline Abies nordmanniana & kavkaska jela & 2 & & & & 2 \\
\hline $\begin{array}{c}\text { Chamaecyparis lawsoniana } \\
\text { (A. Murray) Parl. }\end{array}$ & lawsonov pačempres & 8 & & 1 & 6 & 15 \\
\hline Cryptomeria japonica (L. f.) & japanska kriptomerija & & 1 & & & 1 \\
\hline Larixdecidua Mill. & europski ariš & & 3 & & & 3 \\
\hline Picea abies (L.) Karsten & obična smreka & 59 & 18 & 4 & 38 & 119 \\
\hline Pinus nigra J. F. Arnold & crni bor & 10 & 18 & 4 & 9 & 41 \\
\hline Pinus sylvestris L. & bijeli bor & 6 & 7 & 2 & 1 & 16 \\
\hline Taxus baccata L. & obična tisa & 8 & 4 & & & 12 \\
\hline Ukupno & & $\mathbf{1 0 4}$ & $\mathbf{5 1}$ & $\mathbf{1 1}$ & $\mathbf{5 5}$ & $\mathbf{2 2 1}$ \\
\hline
\end{tabular}

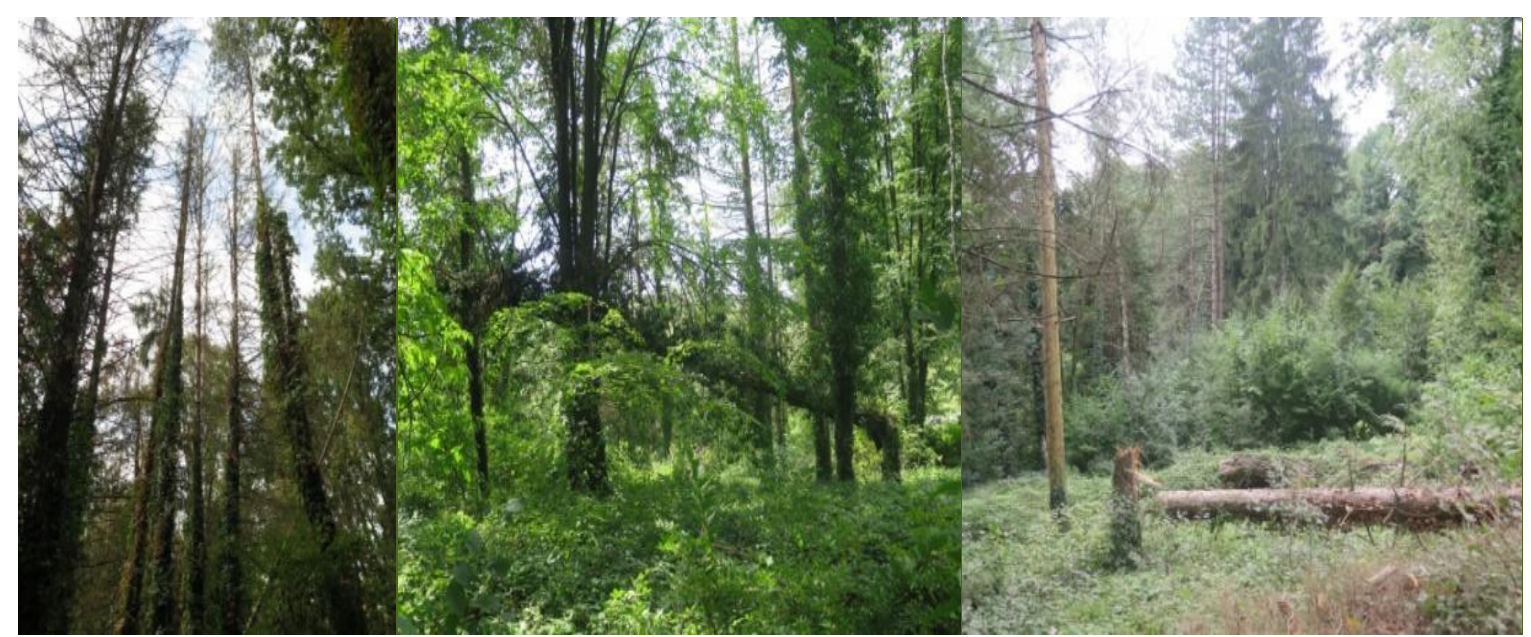

Slika 10. Prizori iz perivoja: nedostatno održavanje, velik broj sušaca i izvaljenih stabala (foto: I. Gašparović).

Figure 10. Scenes from the public garden: insufficient maintenance, large number of droughts and sprawling trees (photo: I. Gašparović).

\section{Smjernice uređenja prostora perivoja}

S obzirom na prostorna obilježja, a sukladno Rješenju Ministarstva kulture, prostor perivoja moguće je podijeliti u dvije osnovne funkcionalne zone, zonu kulturnog dobra (k. č. br. 219) i zonu perivoja (k. č. br. 214/1 i 214/2) koje prostorno gledano čine cjelinu s obzirom na način uporabe te su iste određene kao prostorna međa kulturnog dobra. Stoga će se u smislu analize, valorizacije i prijedloga uređenja obuhvatiti sve tri predmetne čestice kao zona obuhvata (Slika 11). 
Ivana Gašparović, Ž. Španjol, B. Dorbić, I. Tolić, Irena Milčić / Perivoj dvorca Kulmer-Bračak (Republika Hrvatska) - biološko i prostorno vrednovanje / Glasilo Future (2019) 2 (5-6) 01-23

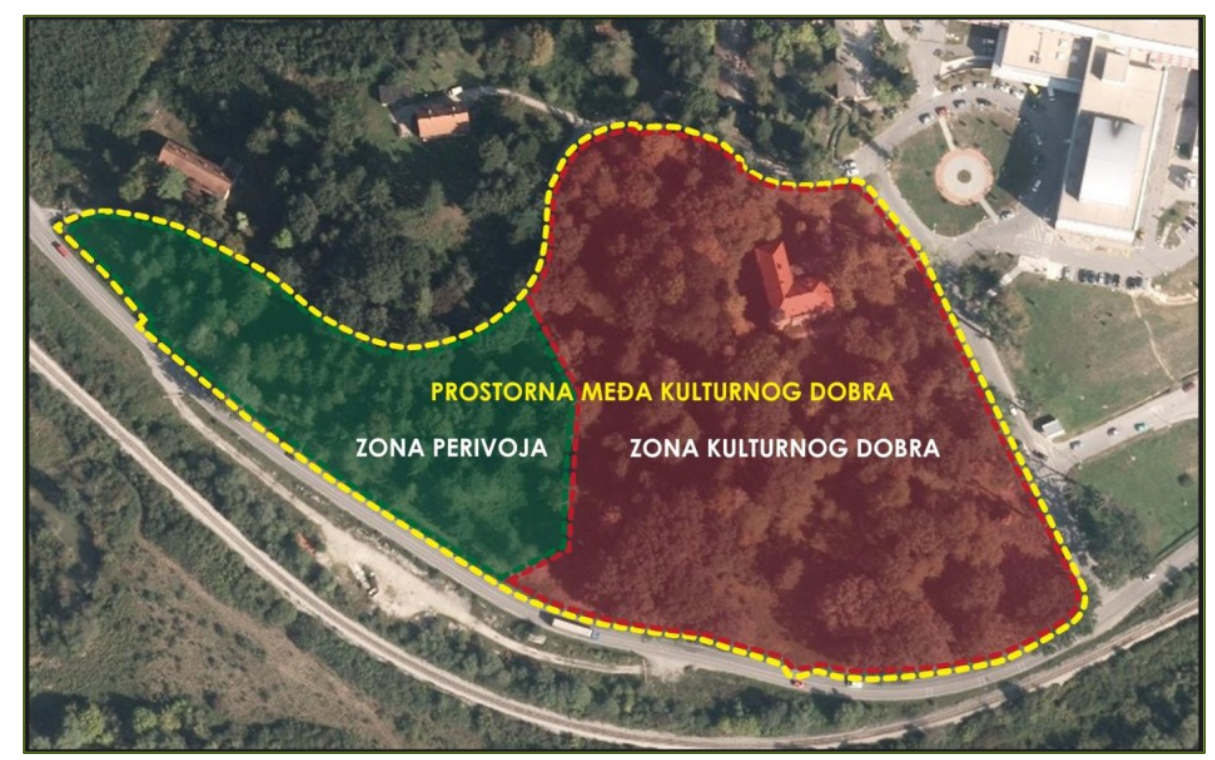

Slika 11. Kartografski prikaz-Zoniranje perivojnog prostora.

Figure 11. Cartographic representation - Zoning of the public garden area.

\section{Zona kulturnog dobra}

- Područje zaštićeno temeljem Zakona o zaštiti i očuvanju kulturnih dobara.

- Prostor koji je evidentiran i kroz povijest katastarskim planom iz 1902. godine.

- Najznačajniji sadržajni element je građevina dvorca.

- Registrirati lokaciju postojećih ostataka parternog vrta te predvidjeti mogućnost restauratorsko-konzervatorskih radova.

- Predvidjeti prostornu organizaciju šetnica i boravišta sukladno starom katastarskom planu.

- Predvidjeti sadržaje u funkciji boravišta.

- Predvidjeti amfiteatar na otvorenom u funkciji edukacijsko-prezentacijskog centra sukladno potrebama REGEA-e.

- Provesti osnovne mjere njege radi očuvanja postojećeg biljnog materijala te predvidjeti zamjensku i novu sadnju.

\section{Zona perivoja}

- U vegetacijskom i prostornom smislu nastavak zone kulturnog dobra.

- Sadržajno povezati sa prethodnom zonom.

- Provesti osnovne mjere njege radi očuvanja postojećeg biljnog materijala te predvidjeti zamjensku i novu sadnju.

\section{Osnovne smjernice uređenja}

- Oformiti pojedine funkcionalne zone sukladno predviđenoj namjeni prostora.

- Predvidjeti uređenje šetnica kako bi se perivojem moglo nesmetano i sigurno komunicirati. 
Ivana Gašparović, Ž. Španjol, B. Dorbić, I. Tolić, Irena Milčić / Perivoj dvorca Kulmer-Bračak (Republika Hrvatska) - biološko i prostorno vrednovanje / Glasilo Future (2019) 2 (5-6) 01-23

- Uz šetnice postaviti klupe za odmor i rasvjetna tijela kako bi se perivojem moglo sigurno komunicirati i noću.

- Kod odabira perivojnih elemenata predvidjeti tip koji izvedbom i materijalom odgovara duhu prostora.

- Provesti sanitarne zahvate biološke osnove (ukloniti suhe i polomljene grane i sušce, iznijeti izvaljena stabla koja su izvor zaraze, povaditi panjeve i dr.), predvidjeti zamjensku sadnju te redovito provoditi osnovne mjere njege, zaštite i očuvanja.

- Prostor perivoja urediti i ozeleniti novom travnom smjesom, te redovito kositi, posebice u zonama uređenja šetnica i zamjene vegetacije gdje će doći do degradacije postojećeg travnjaka uslijed zemljanih radova.

- Na ulazu u perivoj na vidnom mjestu postaviti informativni pano o zaštićenom kulturnom dobru.

\section{Opis idejnog rješenja uređenja prostora perivoja}

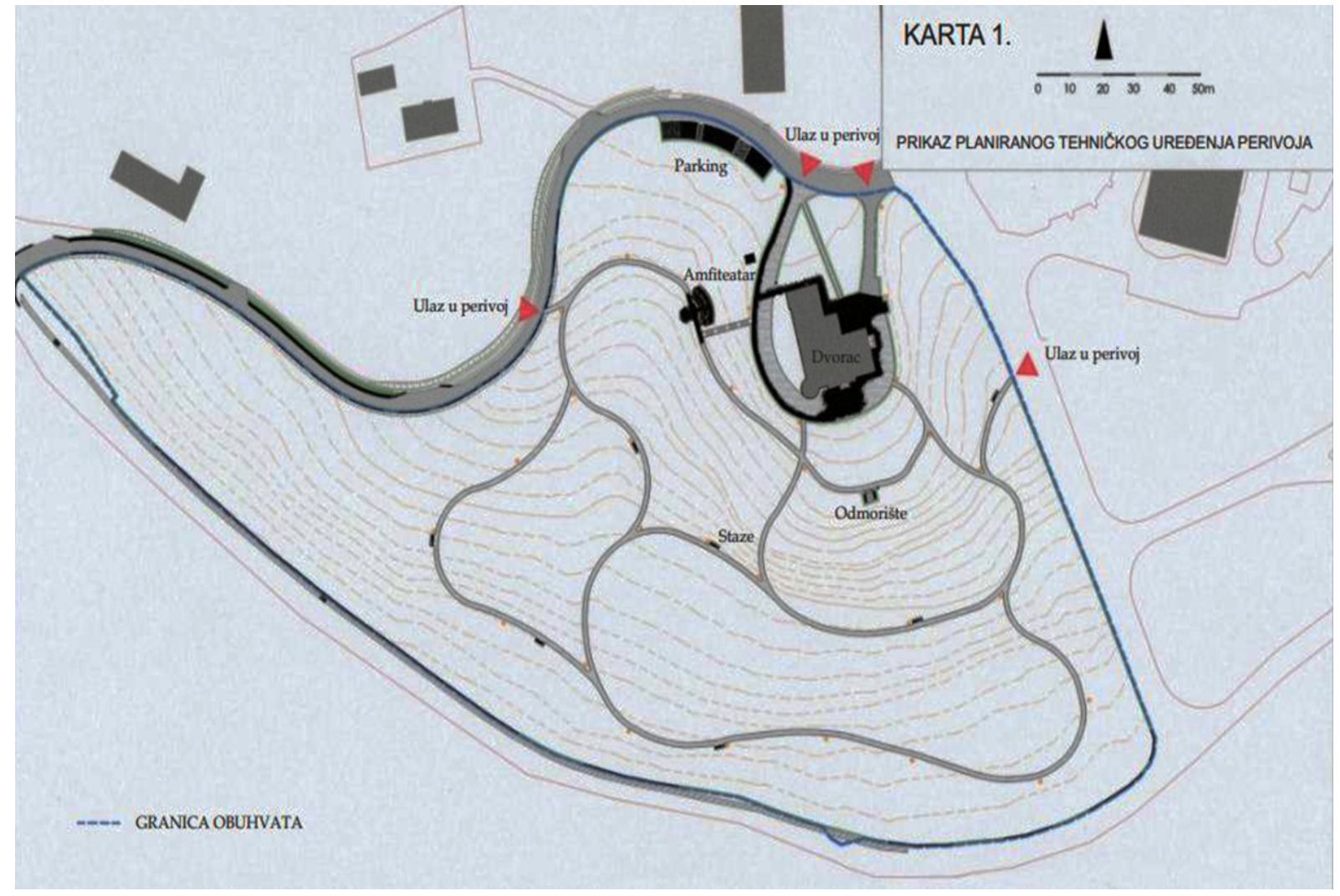

Slika 12. Perivoj Bračak - tlocrt.

Figure 12. Public garden Bračak - layout.

S obzirom da perivoj čini prostornu među kulturnog dobra čime isti ima prvenstveno kulturnopovijesnu vrijednost, organiziranje pojedinih funkcionalnih zona i unošenje novih sadržaja predviđeno je prvenstveno na osnovu povijesne matrice kako bi se u najvećoj mogućoj mjeri sačuvala njegova 
izvornost. Kao izvor korišten je stari katastarski plan iz 1902. godine te dostupne fotografije i razglednice.

Ostali sadržaji koji izvorno ne pripadaju ovom prostoru prilagođeni su njegovoj funkciji kao gradskog parka i potrebama edukacijsko-prezentacijskog centra te organizirani fizičkim i vizualnim uklapanjem sagledavajući ovaj prostor kao jednu nedjeljivu cjelinu na način da se ne narušava njegov osnovni karakter i ambijentalna vrijednost. Kao fizička prepreka u organiziranju perivoja nameću se postojeći objekti koji su danas izvan funkcije. U centralnom dijelu perivoja to je sabirna jama fekalnih voda sa instalacijom stare kanalizacije koja se pruža u smjeru sjever - jug. Na ovoj lokaciji je s obzirom na konfiguraciju terena formiran i prirodni usjek koji uvjetuje otjecanje oborinskih voda i zadržavanje vode tijekom kišnijih razdoblja te je isti potrebno sanirati kvalitetnom drenažom. Drugi objekt je smješten u krajnjem jugoistočnom dijelu perivoja, nekada u funkciji prepumpne stanice. Ti objekti su predviđeni za uklanjanje. Uz sjeverno pročelje dvorca evidentirani su skromni ostaci manjeg parternog vrta koji je uslijed radova na dvorcu krajnje devastiran, a čije je konture još uvijek moguće prepoznati iz ostataka kamenih rubnjaka u čijem središtu stoji element u obliku kamenog stupa ili postolja obraslog u bršljan. Prostor oko samog dvorca treba urediti nakon što završe radovi na njegovoj obnovi i uređenju samog prostora oko dvorca u predviđenoj namjeni. Kako je temeljna vrijednost perivoja upravo biljni materijal, uklapanjem sadržaja se podrazumijeva da se isti organiziraju s obzirom na postojeću vegetaciju kako bi se izbjeglo uklanjanje pojedinih zdravih stabala s ciljem da se postojeći sklop visoke dendroflore sačuva u najvećoj mogućoj mjeri. Provedenom inventarizacijom 2015. godine utvrđena je uznapredovala sukcesija autohtone vegetacije i spontano širenje pojedinih alohtonih vrsta te velik broj sušaca, izvaljenih ili polomljenih stabala i panjeva te smanjen broj jedinki od oko 15 \% u odnosu na inventarizaciju iz 2011. godine. Evidentno je vrlo loše zdravstveno i estetsko stanje perivoja uslijed zapuštenosti i neodržavanja. Potrebno je provesti veće biološke i tehničke zahvate kako bi se isti priveo željenoj funkciji perivoja. Time je prvenstveno potrebno definirati dendrofloru koja će se sačuvati kao osnova perivoja (najstarija zdrava stabla), a predvidjeti uklanjanje kompletnog donjeg nižeg sklopa koji se sukcesivno proširio perivojem uslijed njegovog neodržavanja. Pri tome treba voditi pažnju o eventualnom zadržavanju pojedinih jedinki iz donje etaže (podstojna etaža višeg grmlja) kao zamjenu odumrlim jedinkama iz gornje etaže (drveće). S tim ciljem mi smo u radu napravili odabir stabala i primarno izlučili sve sušce te predvidjeli uklanjanje postojećih izvaljenih ili polomljenih stabala i panjeva te jedinke koje odudaraju od postojećeg koncepta (voćarice, podrast, preblizu dvorcu) te čišćenje terena od niskog raslinja i podrasta tarupanjem, malčiranjem i frezanjem. Tako smo dobili stanje (vrste i njihov broj) koje će bit nositelj budućeg uređenja koncepcije perivoja (Tablice 5. i 6.). Iz tablica je vidljivo da je ostavljeno 446 stabala, od toga 287 listača i 159 četinjača. Dosadašnjim zahvatima između dvije inventarizacije i našim prijedlogom uklanja se 292 stabla. Iako je Regionalni energetski centar u dvorcu Kulmer-Bračak otvoren u ožujku 2017. godine radovi na potpunom funkcionalnom uređenju perivoja nisu urađeni. 
Ivana Gašparović, Ž. Španjol, B. Dorbić, I. Tolić, Irena Milčić / Perivoj dvorca Kulmer-Bračak (Republika Hrvatska) - biološko i prostorno vrednovanje / Glasilo Future (2019) 2 (5-6) 01-23

Tablica 5. Preostala dendroflora listača - perivoj Bračak.

Table 5. Remaining deciduous flora - public garden Bračak.

\begin{tabular}{|c|c|c|c|c|c|c|c|c|c|c|c|c|c|c|c|c|c|}
\hline \multicolumn{2}{|c|}{ Vrsta } & \multicolumn{15}{|c|}{ Broj stabala po debljinskim razredima u cm } & \multirow[b]{2}{*}{$\sum$} \\
\hline Latinski naziv & Hrvatski naziv & $\stackrel{9}{I}$ & $\begin{array}{l}\stackrel{7}{1} \\
=\end{array}$ & $\frac{\overrightarrow{1}}{\mathbf{n}}$ & $\frac{P}{1}$ & $\stackrel{8}{\frac{1}{7}}$ & $\frac{8}{10}$ & $\frac{R}{\frac{1}{6}}$ & 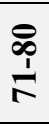 & $\frac{a}{\infty}$ & $\frac{8}{\frac{1}{2}}$ & 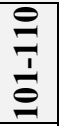 & 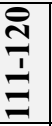 & $\frac{\stackrel{9}{T}}{\frac{1}{\beth}}$ & $\frac{9}{\frac{9}{9}}$ & $\frac{9}{7}$ & \\
\hline Acer campestre $\mathrm{L}$. & klen & 1 & 5 & 4 & 5 & 2 & 1 & & 1 & & & & & & & & 19 \\
\hline Acer negundo L. & javor negundovac & 1 & 1 & 1 & & & & & & & & & & & & & 3 \\
\hline Acer platanoides L. & javor mliječ & 1 & & & & & & & & & & & & & & & 1 \\
\hline $\begin{array}{c}\text { Acer } \\
\text { pseudoplatanus L. }\end{array}$ & gorski javor & & & 3 & 1 & & & & & & & & & & & & 4 \\
\hline $\begin{array}{c}\text { Acer saccharinum } \\
\text { L. }\end{array}$ & srebrnolisni javor & & 2 & 3 & & & & & & & & & & & & & 5 \\
\hline $\begin{array}{c}\text { Aesculus } \\
\text { hippocastanum L. }\end{array}$ & divlji kesten & & & 4 & & & & & & 1 & & & & & & & 5 \\
\hline Betula pendula Roth & obična breza & & & 4 & 13 & 1 & 1 & 1 & & & & & & & & & 20 \\
\hline Carpinus betulus L. & obični grab & & 7 & 8 & 12 & 4 & 3 & 1 & & & & & & & & & 35 \\
\hline Castanea sativa $\mathrm{L}$. & pitomi kesten & & & & & & & & & & & & 1 & & & & 1 \\
\hline $\begin{array}{c}\text { Catalpa } \\
\text { bignonioides Walter }\end{array}$ & katalpa & 1 & 3 & 1 & 1 & 1 & 1 & & & & & & & & & & 8 \\
\hline Corylus avellana $\mathrm{L}$. & obična lijeska & 7 & 3 & & & & & & & & & & & & & & 10 \\
\hline $\begin{array}{c}\text { Fraxinus } \\
\text { angustifolia } \text { Vahl } \\
\end{array}$ & poljski jasen & & & & & & 3 & & & & & & & & & & 3 \\
\hline $\begin{array}{l}\text { Gleditchia } \\
\text { triacanthos } \mathrm{L} .\end{array}$ & trnovac & & & & & 1 & & & & & & & & & & & 1 \\
\hline Juglans regia L. & pitomi orah & 1 & & & & & & & & & & & & & & & 1 \\
\hline $\begin{array}{l}\text { Malus domestica } \\
\text { Borkh. }\end{array}$ & jabuka & & & 1 & & & & & & & & & & & & & 1 \\
\hline Morus alba L. & bijeli dud & & & 1 & & & & & & & & & & & & & 1 \\
\hline $\begin{array}{c}\text { Platanus } x \\
\text { hispanica } \text { Münchh. }\end{array}$ & $\begin{array}{c}\text { javorolisna } \\
\text { platana }\end{array}$ & & & & 1 & 4 & & 2 & 1 & 1 & & 2 & & & & & 11 \\
\hline Prunus avium $\mathrm{L}$. & trešnja & 1 & 1 & & & 1 & 1 & 1 & & & & & & & & & 6 \\
\hline Prunus spinosa $\mathrm{L}$. & crni trn & 1 & & & & & & & & & & & & & & & 1 \\
\hline Quercus robur L. & hrast lužnjak & & 1 & 2 & 13 & 12 & 18 & 13 & 9 & 9 & & 4 & 2 & 1 & & 1 & 85 \\
\hline $\begin{array}{c}\text { Robinia } \\
\text { pseudoacacia } \mathrm{L} .\end{array}$ & obični bagrem & & 4 & 1 & 1 & & & 1 & & & & & & & & & 7 \\
\hline Salix alba L. & bijela vrba & & 1 & & & & & & & & & & & & & & 1 \\
\hline Sorbus torminalis $\mathrm{L}$. & brekinja & & & & & 1 & & & & & & & & & & & 1 \\
\hline Tilia cordata Mill. & sitnolisna lipa & 2 & 2 & 8 & 10 & 13 & 10 & 4 & 3 & & & & & & & & 52 \\
\hline Ulmus glabra Huds. & gorski brijest & & 1 & & & & & & & & & & & & & & 1 \\
\hline Ulmus minor Mill. & poljski brijest & & 2 & & 2 & & & & & & & & & & & & 4 \\
\hline Ukup & & 16 & 33 & 41 & 59 & 41 & 38 & 23 & 14 & 11 & & 6 & 3 & 1 & & 1 & 287 \\
\hline
\end{tabular}

Radovi s biljnim materijalom predviđeni su prvenstveno u svrhu zamjenske sadnje na osnovu stabala predviđenih za uklanjanje te kao nova sadnja u svrhu uređenja perivoja s napomenom da se pri organiziranju novih skupina stabala vodila pažnja i o ostavljanju otvorenih travnatih površina unutar perivoja.

S obzirom na položaj perivoja na vrlo prometnoj lokaciji poželjno je predvidjeti i rubnu sadnju drveća i formiranje živice kako bi se prostor perivoja definirao kao jedna cjelina te vizualno i zvučno zaštitio iznutra. 
Ivana Gašparović, Ž. Španjol, B. Dorbić, I. Tolić, Irena Milčić / Perivoj dvorca Kulmer-Bračak (Republika Hrvatska) - biološko i prostorno vrednovanje / Glasilo Future (2019) 2 (5-6) 01-23

Tablica 6. Preostala dendroflora četinjača - perivoj Bračak.

Table 6. Remaining dendroflora of conifers - public garden Bračak.

\begin{tabular}{|c|c|c|c|c|c|c|c|c|c|c|c|c|}
\hline \multicolumn{2}{|l|}{ Vrsta } & \multicolumn{10}{|c|}{ Broj stabala po debljinskim razredima u cm } & \multirow[b]{2}{*}{$\sum$} \\
\hline Latinski naziv & Hrvatski naziv & $\stackrel{1}{1}$ & 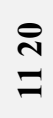 & $\frac{\grave{1}}{\sim}$ & $\underset{\frac{P}{1}}{\stackrel{p}{1}}$ & 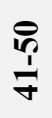 & $\frac{8}{i}$ & $\frac{7}{1}$ & $\underset{\substack{1 \\
i}}{\infty}$ & $\frac{\$}{\infty}$ & $\frac{8}{\frac{1}{6}}$ & \\
\hline Abies alba Mill. & obična jela & & 2 & 5 & 2 & & 2 & & & & & 11 \\
\hline Abies nordmanniana (Steven) & kavkaska jela & & & & & 1 & 1 & & & & & 2 \\
\hline $\begin{array}{l}\text { Chamaecyparis lawsoniana (A. } \\
\text { Murray) Parl. }\end{array}$ & $\begin{array}{l}\text { lawsonov } \\
\text { pačempres }\end{array}$ & & 3 & 3 & 3 & & & & & & & 9 \\
\hline $\begin{array}{c}\text { Cryptomeria japonica (L. f.) D. } \\
\text { Don. }\end{array}$ & $\begin{array}{c}\text { japanska } \\
\text { kriptomerija }\end{array}$ & & & 1 & & & & & & & & 1 \\
\hline Larixdecidua Mill. & europski ariš & & 2 & & 1 & & & & & & & 3 \\
\hline Picea abies (L.) Karsten & obična smreka & 2 & 1 & 5 & 8 & 29 & 22 & 8 & 1 & 2 & 1 & 79 \\
\hline Pinus nigra J. F. Arnold & crni bor & 1 & 1 & 2 & 14 & 8 & 1 & & & & & 27 \\
\hline Pinus sylvestris $\mathrm{L}$. & bijeli bor & & & & 4 & 9 & 1 & 1 & & & & 15 \\
\hline Taxus baccata L. & obična tisa & 2 & 2 & 1 & 3 & 2 & 1 & 1 & & & & 12 \\
\hline Ukupno & & 5 & 11 & 17 & 35 & 49 & 28 & 10 & 1 & 2 & 1 & 159 \\
\hline
\end{tabular}

Novom sadnjom je u najvećem broju predvidjeti pojedinačna sadnja grmlja koje kao perivojni element nije zabilježeno te sanacija postojeće živice i njeno proširenje. Kod odabira vrsta za sadnju predvidjeti pretežito autohtone vrste i vrste koje su kroz povijest evidentirane u perivojima na području Hrvatskog zagorja. Drveće koje predviđamo za sadnju je Abies nordmanniana (Steven) Spach - Nordmanska jela, Acer platanoides L. - javor mliječ, Betula pendula Roth. - obična breza, Carpinus betulus L. - obični grab, Catalpa bignonioides Walter - katalpa, Chamaecyparis lawsoniana (A. Murray) Parl. - Lawsonov pačempres, Crataegus monogyna Jacq. - glog, Fraxinus angustifolia Vahl - poljski jasen, Juglans nigra L. - crni orah, Liriodendron tulipifera L. - tulipanovac, Salix alba'Tristis' L. - žalosna vrba 'Tristis', Taxus baccata L. - obična tisa, Tilia cordata Mill. - malolisna lipa, Ulmus glabra Huds. - gorski brijest, Quercus robur L. - hrast lužnjak. Od grmlja predlaže se za sadnju Cornu salba 'Sibirica' - dren, Cotoneaster dammeri C. K. Schneid. - puzajuća dunjarica, Euonymus europaeus L. - obična kurika, Forsythia x intermedia - forzicija, Philadelphus coronarius L. - pajasmin, Spirea $x$ vanhouttei - suručica, Viburnum rotundifolia L. - hudika, Weigela florida Thunb. - vajgelija. Za sadnice grmlja za živicu predlažemo sukladno prijašnjem stanju perivoja Buxus sempervirens L. - šimšir i Carpinus betulus L. - grab. Kao pokrivač tla svakako treba uzeti Vinca minor L. - mali zimzelen .

Kao zanimljivost u užem obuhvatu oko dvorca, na njegovoj južnoj strani, evidentirana je stara platana koju je podnom rasvjetom moguće učiniti akcentom u prostoru. Zbog velikog broja atraktivnih starih stabala moguće je akcent staviti na više njih (platane, hrastovi, tise i druge).

U rubnom najnižem južnom dijelu perivoja određene su tri mikrolokacije kao prirodne depresije u kojima se zadržava voda, a koja uvjetuje vlažno stanište na kom prirodno pridolaze perunike (Iris pseudacorus L.). Ove lokacije su sačuvane kao akcenti u perivoju. U zapadnom dijelu perivoja zatičemo veće grupacije crnogoričnih vrsta, pretežno smreke (Picea abies (L.) H. Karst.), s kojom je 
Ivana Gašparović, Ž. Španjol, B. Dorbić, I. Tolić, Irena Milčić / Perivoj dvorca Kulmer-Bračak (Republika Hrvatska) - biološko i prostorno vrednovanje / Glasilo Future (2019) 2 (5-6) 01-23

predviđena sadnja breze (Betula pendula Roth.) koja svojom bijelom ispucanom korom kontrastira tamnoj crnogorici i čini još jedan akcent u prostoru perivoja. Osnova povezivanja prostora perivoja trebaju biti šetnice organizirane na osnovu katastarskog plana iz 1902. godine na kom se iste jasno čitaju. Kako su granice perivoja izmijenjene kao i zatečeno stanje u odnosu na povijesno razdoblje, izvođenje identičnih staza nije moguće, ali treba zadržati način njihovog organskog oblikovanja i njihove organizacije prilagođene konfiguraciji terena. Raster staza će biti umanjen sukladno današnjim potrebama i namjeni perivoja kao i okolnog prostora. Pristup perivoju predvidjeti sa tri strane, iz smjera sjevera sa platoa oko dvorca te iz smjera istoka i zapada, s postojećih asfaltiranih cesta koje ga okružuju. U izvedbi staza kroz perivoj predviđena je uporaba sipine, a kod izvedbe staze na kosinama izvedba jednostavnih stepenica $\mathrm{u}$ sipini $\mathrm{s}$ dužim podestima prilagođenim nagibima s potporom od drvenih elemenata. Prostor platoa oko dvorca treba zadržati u postojećoj površini s manjim korekcijama sukladno prometnom elaboratu i potrebama pristupa vatrogasnog vozila. Izvedbu platoa predvidjeti u kombinaciji sipine i popločenja od prirodnih materijala (granitna kocka ili opeka). Glavna komunikacija koja prolazi kružno oko dvorca, povezuje pristup dvorcu sa asfaltne ceste, sva tri ulaza u dvorac, terasu ispred južne fasade dvorca i stepenice koje vode prema amfiteatru treba biti popločana staza. Staza je predviđena u širini od 1,20 m plus prijelaz u sipinu s kojom staza nema jasnu granicu već se gubi miješanjem elemenata opločnika i sipine.

U smislu pojedinih funkcionalnih zona i sadržaja njihovo lociranje je predviđeno u odnosu na postojeći dvorac i povijesnu matricu perivoja iz koje je proizašlo organiziranje šetnica. U svrhu zadržavanja identiteta prostora kod odabira sadržaja predvidjeti upotrebu materijala i dizajna kojim će se poštivati kriteriji autentičnosti. Postojeće boravište u šimširu smješteno južno od dvorca zadržati u svom izvornom obliku. Od novih sadržaja predvidjeti unošenje osnovnih perivojnih elemenata u obliku klupa, koševa za otpatke i rasvjetnih tijela smještenih uz šetne staze čime se omogućava dulje zadržavanje te ugodniji i sigurniji boravak u perivoju. Organiziranje manjeg amfiteatra, sukladno potrebama edukacijsko-prezentacijskog centra, predviđeno je prema konfiguraciji terena uklapanjem u padinu dvorca s njegove zapadne, u odnosu na glavni ulaz i stražnje strane. S obzirom na okolne prometnice ova lokacija je povoljna i u smislu manje izloženosti buci. Izvedbu amfiteatra predvidjeti od prirodnih materijala, oblaganjem u drvo i popločenjem od granita ili opeke. Time se izravno ne narušava povijesni prostorni i arhitektonski sklop dvorca i perivoja, a doprinosi se upotrebi prostora. Postavljanjem informativnog panoa $\mathrm{s}$ informacijama o genezi dvorca i perivoja doprinosi se saznanjima o nacionalnoj i regionalnoj povijesti i kulturi.

\section{Zaključak}

$\mathrm{Na}$ osnovu arhivske građe te inventarizacije i analize perivoja proizlazi činjenica o njegovom nedostatnom istraživanju, dokumentiranju i vrednovanju, što je nadalje i uzrok nepostojanja potrebnih mjera zaštite i očuvanja. Ipak, na temelju katastarskih karata i dostupnih fotografija te današnjih 
Ivana Gašparović, Ž. Španjol, B. Dorbić, I. Tolić, Irena Milčić / Perivoj dvorca Kulmer-Bračak (Republika Hrvatska) - biološko i prostorno vrednovanje / Glasilo Future (2019) 2 (5-6) 01-23

skromnih ostataka strukture perivoja, moguće je donijeti zaključak o njegovoj vrijednosti i važnosti. Tako prostornu vrijednost prepoznajemo iz osobite kvalitete smještaja u prirodnom krajobrazu iz kojeg proizlaze i iznimne vizualne kvalitete. Prirodne, krajobrazne i graditeljske vrijednosti međusobno se isprepliću i međusobno uvjetuju iz čega proizlazi činjenica da kulturno i prirodno nasljeđe predstavljaju harmoničnu cjelinu, čiji su elementi nedjeljivi i koje kao takve treba održavati. Iz toga proizlazi dugogodišnja kulturno-povijesna vrijednost koja se manifestira kroz ostatke građevine dvorca i koji ukazuju i na stilsku vrijednost, umjetničku vrijednost te vrijednost rijetkosti. Naposljetku, kroz funkciju upoznavanja nacionalne i regionalne povijesti i kulture, perivoj ukazuje i na svoju odgojno-obrazovnu, etnološku i gospodarsku važnost kao turistička atraktivnost.

Uređenjem i obnovom perivoja treba težiti naglašavanju svih njegovih vrijednosti koje se trebaju valorizirati u širem kontekstu sagledavajući ovaj prostor kao jednu nedjeljivu cjelinu čiji se elementi isprepliću i međusobno nadopunjavaju. Revitalizacija kao metoda obnove koja podrazumijeva vraćanje života u napuštene ili zapuštene objekte i perivoje time što im se vraća prvobitna ili pridaje neka druga primjerena funkcija, čime se ne smije dovesti u pitanje osnovni karakter i kvaliteta povijesne perivojne arhitekture, može i u ovom slučaju biti misao vodilja (Obad-Šćitaroci, 1992). Regionalni energetski centar u dvorcu Kulmer-Bračak otvoren je u ožujku 2017. godine dok radovi na potpunom funkcionalnom uređenju perivoja još nisu urađeni. Iako se u smislu stilskih obilježja i perivojnih sadržaja predmetno područje ne ističe osobitim vrijednostima, one se mogu upotpuniti njihovim unošenjem dok bi se učinkovitijim provođenjem neophodnih mjera održavanja i zaštite svakako doprinijelo očuvanju izvornih vrijednosti i identiteta prostora.

Temeljem izrade rada došlo se do spoznaja da perivoj ima prvenstveno kulturno-povijesnu vrijednost. Organiziranje pojedinih funkcionalnih zona i unošenje novih sadržaja predviđeno je na osnovu povijesne matrice zbog očuvanja izvornosti. Preostali sadržaji koji autentično ne pripadaju ovom prostoru prilagođeni su njegovoj funkciji kao gradskog parka i potrebama edukacijsko-prezentacijskog centra na način da se ne narušava njegov osnovni karakter i ambijentalna vrijednost.

Budući je temeljna vrijednost perivoja biljni materijal, uklapanjem sadržaja se podrazumijeva da se isti uklope na postojeću vegetaciju. Sukladno provedenoj inventarizaciji i analizi utvrđeno je i vrlo loše estetsko i zdravstveno stanje perivoja uslijed zapuštenosti i neodržavanja. Radovi s biljnim materijalom predviđeni su prvenstveno u svrhu zamjenske sadnje i to na osnovu stabala predviđenih za uklanjanje te kao nova sadnja. Novom sadnjom je predviđena pojedinačna sadnja grmlja. Kod odabira vrsta za sadnju važnost dati autohtonim vrstama i vrstama koje su kroz povijest evidentirane u perivojima na području Hrvatskog zagorja. U rubnom najnižem južnom dijelu perivoja određene su tri mikrolokacije kao prirodne depresije u kojima se zadržava voda kao akcenti u perivoju. Osnova povezivanja prostora perivoja jesu šetnice organizirane na osnovu katastarskog plana iz 1902. godine. U smislu pojedinih funkcionalnih zona i sadržaja njihovo lociranje je predviđeno u odnosu na postojeći dvorac i povijesnu matricu perivoja iz koje je proizašlo organiziranje šetnica. 
Ivana Gašparović, Ž. Španjol, B. Dorbić, I. Tolić, Irena Milčić / Perivoj dvorca Kulmer-Bračak (Republika Hrvatska) - biološko i prostorno vrednovanje / Glasilo Future (2019) 2 (5-6) 01-23

\section{Literatura}

Čandrlić, C. (2005): Od dvorca Bračak do nove bolnice Bračak, Hrvatsko zagorje - časopis za kulturu, XI:1.

Gregurić, G. (2009): Kulmer. Zabok: Ekološko društvo "Lijepa naša".

Habe, J. (2009): 120 godina Kulmera na Bračku. Glasilo Opće bolnice Zabok.

Milčić, I. (2013): Perivoj Bračak - krajobrazno vrednovanje i prijedlog za zaštitu, Diplomski rad, Šumarski fakultet Sveučilišta u Zagrebu.

Obad-Šćitaroci, M. (1991): Dvorci i perivoji Hrvatskoga zagorja. Zagreb: Školska knjiga.

Obad-Šćitaroci, M. (1992): Hrvatska parkovna baština: zaštita i obnova. Zagreb: Školska knjiga.

Prostorni plan uređenja Grada Zaboka (2009), I. Izmjene i dopune PPUGZ (2011), II. Izmjene i dopune PPUGZ (2013) i III. Izmjene i dopune PPUGZ (2015).

Vukelić, J. (2012): Šumska vegetacija Hrvatske. Zagreb: Sveučilište u Zagrebu, Šumarski fakultet, DZZP.

\section{Ostali izvori:}

Geoportal Državne geodetske uprave.

Hrvatski državni arhiv, HRHDA, Fond 739: Obitelj Kulmer.

Hrvatski državni arhiv, HRHDA, Fond 1421: Katastarski plan posjeda Bračak iz 1902. g.

Ministarstvo kulture, Konzervatorski odjel u Krapini.

Ustupljene podloge od strane koordinatora (REGEA): Novi katastarski plan (2016), prometni elaborat.

Primljeno: 06. prosinca 2019. godine

Prihvaćeno: 30. prosinca 2019. godine
Received: December 06, 2019

Accepted: December 30, 2019 